\title{
Bacterial Nosocomial Infections: Multidrug Resistance as a Trigger for the Development of Novel Antimicrobials
}

\author{
Sílvia A. Sousa ${ }^{1,2, * \mathbb{D}}$, Joana R. Feliciano ${ }^{1,2} \mathbb{D}$, Tiago Pita ${ }^{1,2} \mathbb{D}$, Catarina F. Soeiro ${ }^{1} \mathbb{D}$, Beatriz L. Mendes ${ }^{1,3} \mathbb{( D}$, \\ Luis G. Alves ${ }^{4}$ and Jorge H. Leitão $1,2, * \mathbb{D}$
}

1 Department of Bioengineering, IBB-Institute for Bioengineering and Biosciences, Instituto Superior Técnico, Universidade de Lisboa, Av. Rovisco Pais, 1049-001 Lisboa, Portugal; joana.feliciano@tecnico.ulisboa.pt (J.R.F.); tiagopita@tecnico.ulisboa.pt (T.P.); catarina.soeiro25@gmail.com (C.F.S.); abeatrizmendes@tecnico.ulisboa.pt (B.L.M.)

2 Associate Laboratory i4HB-Institute for Health and Bioeconomy at Instituto Superior Técnico, Universidade de Lisboa, Av. Rovisco Pais, 1049-001 Lisboa, Portugal

3 Centro de Química Estrutural, Instituto Superior Técnico, Universidade de Lisboa, 1049-001 Lisboa, Portugal

4 Centro de Química Estrutural, Associação do Instituto Superior Técnico para a Investigação e Desenvolvimento, 1049-003 Lisboa, Portugal; luis.g.alves@tecnico.ulisboa.pt

* Correspondence: sousasilvia@tecnico.ulisboa.pt (S.A.S.); jorgeleitao@tecnico.ulisboa.pt (J.H.L.); Tel.: +351-218417688 (J.H.L.)

check for updates

Citation: Sousa, S.A.; Feliciano, J.R.; Pita, T.; Soeiro, C.F.; Mendes, B.L.; Alves, L.G.; Leitão, J.H. Bacterial Nosocomial Infections: Multidrug Resistance as a Trigger for the Development of Novel Antimicrobials. Antibiotics 2021, 10, 942. https://doi.org/10.3390/ antibiotics 10080942

Academic Editor: Óscar Murillo

Received: 4 July 2021

Accepted: 30 July 2021

Published: 4 August 2021

Publisher's Note: MDPI stays neutral with regard to jurisdictional claims in published maps and institutional affiliations.

Copyright: (c) 2021 by the authors. Licensee MDPI, Basel, Switzerland. This article is an open access article distributed under the terms and conditions of the Creative Commons Attribution (CC BY) license (https:// creativecommons.org/licenses/by/ $4.0 /)$.

\begin{abstract}
Nosocomial bacterial infections are associated with high morbidity and mortality, posing a huge burden to healthcare systems worldwide. The ongoing COVID-19 pandemic, with the raised hospitalization of patients and the increased use of antimicrobial agents, boosted the emergence of difficult-to-treat multidrug-resistant (MDR) bacteria in hospital settings. Therefore, current available antibiotic treatments often have limited or no efficacy against nosocomial bacterial infections, and novel therapeutic approaches need to be considered. In this review, we analyze current antibacterial alternatives under investigation, focusing on metal-based complexes, antimicrobial peptides, and antisense antimicrobial therapeutics. The association of new compounds with older, commercially available antibiotics and the repurposing of existing drugs are also revised in this work.
\end{abstract}

Keywords: nosocomial infections; multidrug-resistant (MDR) bacteria; novel antimicrobial agents; drug repurposing; metal-based complexes; antimicrobial peptides; antisense antimicrobial therapeutics

\section{Introduction: Bacterial Nosocomial Infections}

Nosocomial infections (also known as "healthcare associated infections"- - HAI) are an important cause of morbidity and mortality worldwide, being associated with a substantial increase in prolonged hospital stay and healthcare costs. According to the European Centre for Disease Prevention and Control (ECDC), a total of 8.9 million HAIs occur each year in European acute care hospitals and long-term care facilities [1]. The populations with increased risk of infections are patients in intensive care units (ICUs), surgical units, oncology/hematology units, burn units, and those undergoing organ transplant and neonates [2,3]. The most common nosocomial infections are catheter-associated urinary tract infections (CAUTI), surgical site infections (SSI), central line-associated bloodstream infections (CLABSI), ventilator-associated pneumonia (VAP), and Clostridioides difficile infections (CDI) [4]. Several sources of bacterial nosocomial infections have been described, including surgery procedures and invasive devices such as catheters and ventilators [4].

Several bacterial pathogens have been associated with HAI infections, with the most common HAIs being caused by Acinetobacter baumannii, Burkholderia cepacia complex (Bcc), Pseudomonas aeruginosa, C. difficile, Clostridium sordellii, extended-spectrum beta-lactamase (ESBL)-producing and carbapenemase-producing Enterobacterales (CPE), vancomycinresistant Enterococci (VRE), Staphylococcus aureus (including methicillin-resistant S. aureus 
(MRSA), vancomycin-intermediate S. aureus (VISA), and vancomycin-resistant S. aureus (VRSA)), Mycobacterium tuberculosis, and nontuberculous mycobacteria (NTM). One of the major problems associated with these infections is the increased resistance of bacteria to the clinically available antibiotics. In 2019, the Center for Disease Control and Prevention (CDC) reported more than 2.8 million antibiotic-resistant infections in the United States each year, and more than 35,000 related deaths [5]. In 2019, from the above HAI common infections, the CDC included in their urgent threat list the carbapenem-resistant Acinetobacter, carbapenem-resistant Enterobacterales (CRE), and C. difficile [5]. Carbapenem-resistant Acinetobacter are common in ICU patients and can cause pneumonia, as well as wound, bloodstream, and urinary tract infections [6]. The control of the spread of such infections is challenging because it frequently contaminates healthcare facilities' surfaces and shared medical equipment, causing outbreaks in these facilities [6]. CRE are one of the major concerns for patients in healthcare facilities, principally among patients requiring invasive devices (e.g., catheters) or who have long antibiotic therapy, because some bacteria of this family are resistant to nearly all antibiotics available [7]. C. difficile infections can cause life-threatening diarrhea and are often acquired after antibiotic treatment for other medical conditions, with the most serious infections being developed after the use of fluoroquinolones [5,8]. These infections are more common and severe in older patients [5,8].

Bacterial resistance even to one antibiotic can be a serious problem to hospitalized patients, because the use of second- and third-line treatments can have serious side effects for the patients and prolong care and recovery, sometimes for months [5]. Therefore, infection preventive measures and antibiotic stewardship are the priority in healthcare facilities to decrease the spread of antibiotic-resistant bacterial pathogens.

\section{Antimicrobial Resistance Mechanisms of Bacterial Nosocomial Pathogens}

Antimicrobials are commonly used in acute care hospitals for the treatment of both community-acquired infections and HAIs, and also for surgical prophylaxis. However, several studies have shown that this use is commonly performed using incorrect antimicrobial selection, dose, route of administration, and even the duration of the treatment [9]. This inappropriate use of antibiotics, especially broad-spectrum antibiotics, leads to the emergence and spread of antimicrobial-resistant (AMR) bacteria [10]. Another problem with unnecessary antibiotic use is the associated side effects (e.g., allergic reactions and toxicity that affects organ function) and the disruption of the human gastrointestinal microbiome, with the patient being at risk of developing problematic gut infections such as C. difficile [11].

Currently, the coronavirus disease 2019 (COVID-19) pandemic is boosting the use of antibiotics that could lead to the increase in AMR bacteria, because COVID-19-hospitalized patients often receive empiric broad-spectrum antibiotic therapy [12]. Besides that, hospitalization increases the risk of acquiring HAIs and also contributes to the increased use of antimicrobials [12]. Another problem is the prioritized allocation of isolation rooms to COVID-19 patients, causing cohorting and/or management in open bays of patients colonized with VRE, MRSA, CPE, or C. difficile, and the higher workload of healthcare workers can lead to a greater number of hospital transmissions [13].

The main cellular targets of the currently available antibiotics are the cell wall synthesis, protein synthesis, RNA polymerase, DNA replication, and folic acid metabolism [14]. The inhibition of cell wall synthesis and function, through disruption or damage of this structure, results in leakage of important solutes crucial for cellular functions, leading to cell death. The $\beta$-lactam class of antibiotics, which includes penicillins, cephalosporins, cephamycins, and carbapenems, targets the cell wall biosynthesis in bacteria. Additionally, antibiotics such as vancomycin, daptomycin, and bacitracin also interact with bacterial cell wall biosynthesis. Another mechanism of action is the inhibition of protein synthesis via irreversible binding to the $30 \mathrm{~S}$ or $50 \mathrm{~S}$ subunits of the ribosome. This attachment to the ribosomes results in protein synthesis interruption or in damaged proteins. As proteins are the building blocks of most cellular structures, disrupting their synthesis 
collapses the normal bacterial metabolism, causes death, or inhibits bacterial growth. This antibiotic class includes aminoglycosides, tetracyclines, macrolides, and streptogramins. Another antibiotic class acts by inhibition of nucleic acid synthesis by bonding to crucial components involved in DNA and RNA synthesis, and includes quinolones and rifampin. These two essential cell components are fundamental for all metabolic processes, therefore the dysregulation of the synthesis of nucleic acids will compromise bacterial multiplication and survival. Antibiotics can also be classified as antimetabolites, including sulfonamides and trimethoprim, which are responsible for the inhibition of other metabolic processes and act on selected cellular processes decisive for the survival of microorganisms.

However, selective pressure over bacteria leads to the emergence of resistance mechanisms, such as alterations in the outer membrane permeability, overexpression of efflux pumps, modification of the target molecule, or antibiotic inactivation [15] (Figure 1). These resistance-gene traits can be intrinsic or they can pass horizontally by mobile genetic elements [15]. The bacterial mechanisms of resistance to antibiotics have been extensively reviewed [16,17].

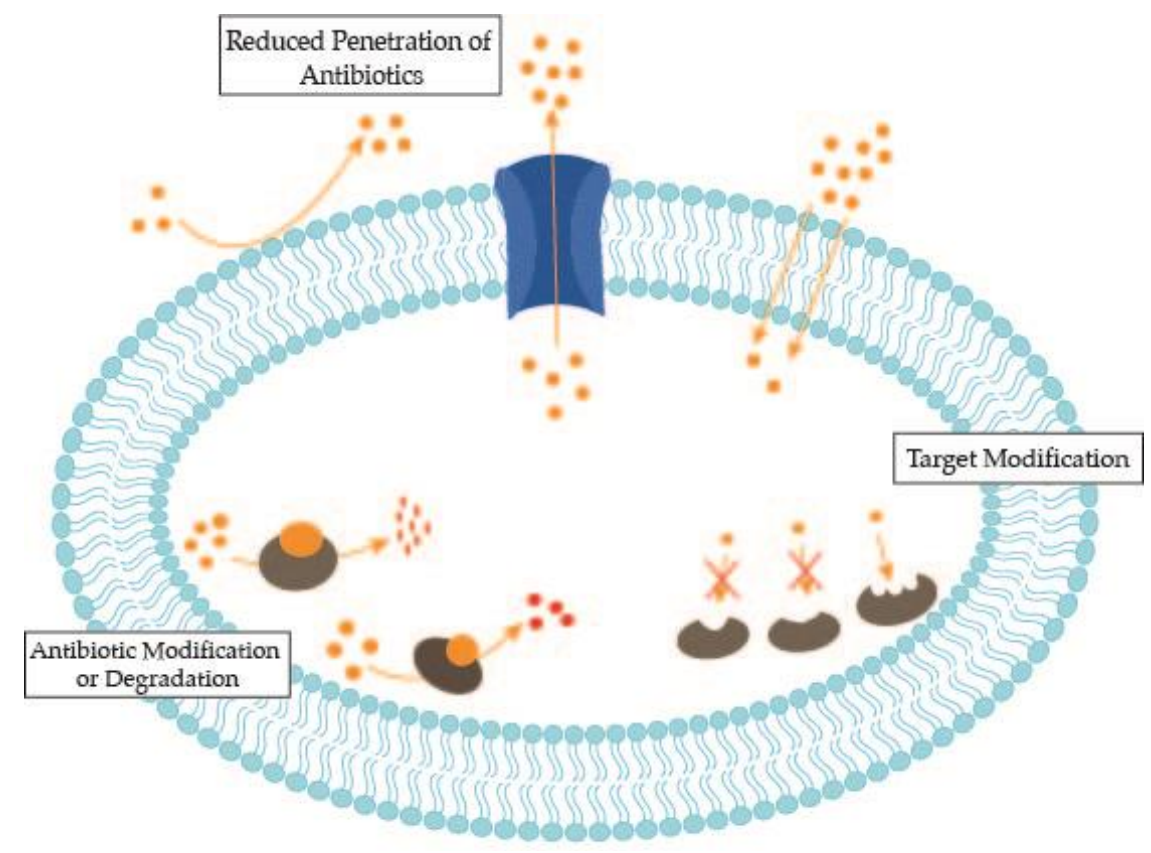

Figure 1. Mechanisms used by bacteria to resist antimicrobials.

Due to the alarming increase of bacterial resistance rate to several antibiotics and the higher morbidity and mortality caused by these resistant bacterial strains, the Infectious Disease Society of America (IDSA) selected six priority pathogens termed ESKAPE (Enterococcus faecium, S. aureus, Klebsiella pneumoniae, A. baumannii, P. aeruginosa, and Enterobacter cloacae) as the bacterial group requiring a rapid development of new antibacterials [18].

\section{Antimicrobial Alternatives under Investigation}

The development and marketing approval of new antibiotics is far behind the increasing emergence of drug-resistant bacteria. The majority of pharmaceutical companies have scaled back, or even cut, antibiotic research programs due to the increase of development challenges. In fact, only one out of five infectious disease drugs that have started testing in humans is expected to receive approval from the US Food and Drug Administration (FDA) [5]. In contrast, several research groups worldwide are focusing on the development of novel antimicrobials based on molecules with new modes of action or distinct interacting targets from those already known. The ideal antibacterial agent should be also nontoxic to the host and should have exceptional blood/fluid circulation, as well as absorption, distribution, metabolism, and excretion (ADME) properties, allowing a large therapeutic 
window with a low dose [14]. However, the process of drug development from a new drug discovery to commercialization is exhaustive and lengthy (Figure 2).

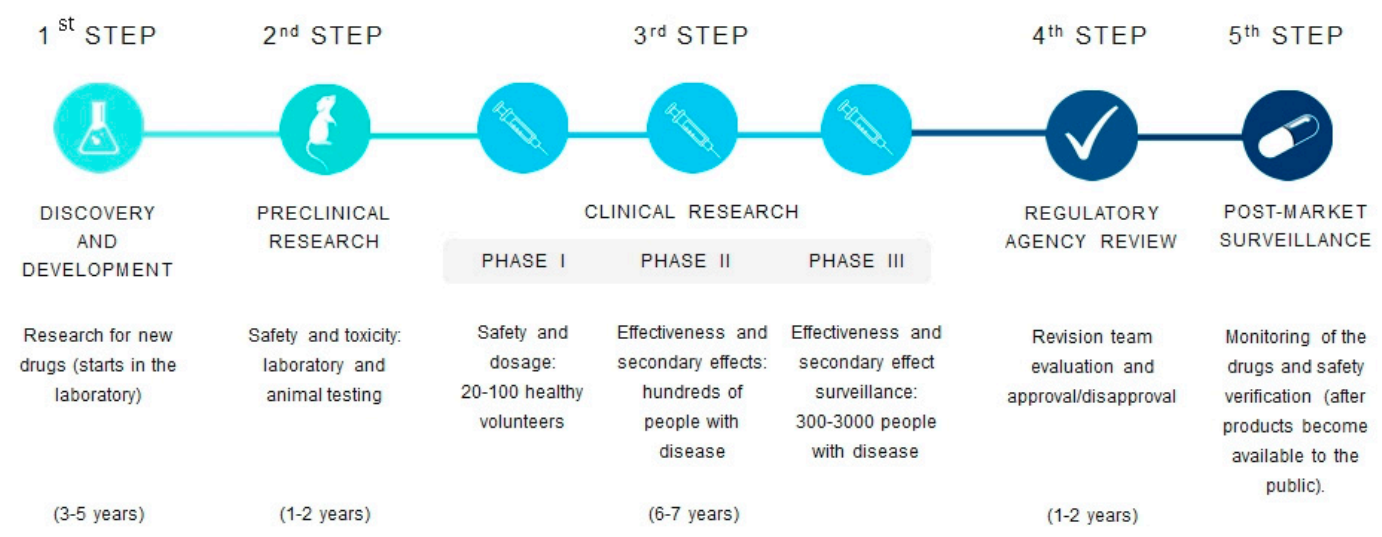

Figure 2. Drug discovery and development pipeline.

Despite this shortage of arrival of novel antimicrobial compounds to the market, many research groups drive their attention to the development of novel compounds and formulations to tackle the emergence of multidrug resistance. Several approaches have been developed to combat microbial infections, including the repurpose of existing drugs, the use of new delivery systems such as metal nanoparticles, the development of new compounds such as organic compounds and metal complexes, microbial metabolism-disrupting compounds such as iron and zinc chelators, antimicrobial peptides, and antisense antimicrobial therapeutics. In this review we focus on developments of the repurposing of existing drugs, novel metal-based complexes, antimicrobial peptides, and antisense antimicrobial therapeutics.

\subsection{Repurposing of Existing Drugs}

A strategy that is increasingly employed as a way of providing new drugs able to overcome the struggle of antibiotic resistance is drug repurposing. As the name implies, it consists of finding a new applicability to existing drugs, rather than their primary medical indication [19]. This approach has become especially important in an industry where the output has not been compensating the spending in the pharma resources and development and the pressure imposed by the high prices, generics' competition, and regulatory issues, altogether inflicting a hard challenge for the discovery of new drugs [20].

Drug repurpose is rooted in two prepositions: drugs that act on various targets, and diseases that share the same biological targets [21]. Candidates to be repurposed must be drugs in clinical development or drugs safety evaluated, although having failed to show efficacy in late clinical trials. Moreover, the ones that had their project interrupted due to commercial issues are under exploitation in new geographical markets or, despite being already in the market, have generic or close to expiring patents, and thus can also be assigned to new medical indications [22].

The repurposing approach offers many advantages over de novo drug discovery and development. Indeed, there is a significant reduction of the processing time and development risks and costs, since repositioning candidates' pharmacokinetic and safety profiles are already determined due to the stages of clinical development they went through [19]. In some cases, they were also submitted to other development steps, such as in vitro and in vivo screening, chemical optimization, and toxicology, which are steps that can therefore be skipped [19].

Driving the attention to MDR pathogens, there are a variety of drugs used to treat pathological conditions of noninfectious origin that have demonstrated in vitro and in vivo broad-spectrum of antimicrobial activity. Those are normally called "nonantibiotics" and can express antibacterial properties by having direct antimicrobial activity (antimicrobial 
nonantibiotics), enhancing the effectiveness of an antibiotic when coadministered (synergism; helper compounds), or impairing the microorganisms' pathogenicity and activity, similar to modulating the activity of macrophages [23,24].

Among the existing drugs, many have proven their efficacy against MDR pathogens. Some similarities between cancer and bacterial cells have been found, such as the higher rates of replication and resistance development against chemotherapeutic agents, virulence, spread modalities within the host, and increasing aggressiveness as disease develops [25]. Thus, it is not surprising that a variety of anticancer agents, such as mitomycin C, cisplatin, and gallium, have proven their ability to fight bacteria, by crosslinking DNA or disrupting iron metabolism [26-30].

Interestingly, known for being associated with a decreased risk of sepsis, statins' antimicrobial properties were unveiled by Jenwood and Cohen, especially against methicillinsensitive S. aureus (MSSA), MRSA, vancomycin-sensitive Enterococci (VSE), and VRE bacteria [31].

The antimicrobial activity of the antihelmintic niclosamide was uncovered by Imperi et al. [32], after screening a library of FDA-approved drugs for their capacity to inhibit the quorum-sensing (QS) response of P. aeruginosa. Similarly, the antihistamine terfenadine was identified when searching for drugs with bactericidal activity against ESKAPE pathogens, and further confirmed by Perlmutter et al. to be active towards S. aureus [33]. In another study, when screening 1280 off-patent FDA-approved drugs for the inhibition of GraXRS, a two-component system of $S$. aureus, the photosensitizer verteporfin, was the most efficient in increasing polymorphonuclear (PMN)-mediated bacterial killing and reducing the bacterial load in a murine model of surgical wound infection [34].

Anesthetic drugs' antimicrobial properties were first suggested in 1909, propelling further research on this topic. Aydin et al. confirmed the antimicrobial action of lidocaine and prilocaine against $P$. aeruginosa, E. coli, and S. aureus. These authors hypothesized that the antimicrobial properties of local anesthetics used for spinal or epidural anesthesia might be the reason for meningitis and other infective neurological complications being uncommon [35]. Opioids have also been applied to pain management via the epidural route, and Grimmond and Brownridge proved the antibacterial activity of pethidine against MRSA, S. aureus, E. coli, and P. aeruginosa [36].

Auranofin, an $\mathrm{Au}(\mathrm{I})$ thiolate complex, was introduced and approved by the FDA in 1985 for rheumatoid arthritis, but the toxic side effects impelled the search for less-toxic alternatives [37]. Presently, with the aim of performing drug "repurposing", auranofin has gained increased attention, and many studies have been conducted in order to find out its mechanism of action [37]. Auranofin's therapeutic effects have been investigated for cancer, neurodegenerative diseases, HIV / AIDS, and parasitic and bacterial infections. Harbut et al. showed that auranofin can impair the redox balance in S. aureus by strongly inhibiting thioredoxin reductase (TrxR) and consequently compromising their cellular defense against oxidative stress [38]. In the same study, the synergistic effect of paraquat (reactive oxygen species (ROS) generator) with auranofin was confirmed to be effective, which corroborated the damage of Trx-TrxR by auranofin and showed that this association compromises cellular defenses against oxidative stress and increases bacterial death [38]. Another interesting experiment was performed by Fuchs et al., who, after checking a higher efficacy of auranofin against Gram-positive (GSH-lacking) bacteria, tested glutathione as an antagonist of this gold complex [39]. When glutathione was introduced in auranofin Grampositive sensitive bacteria, the MIC value of auranofin was enhanced, which reinforced the Trx system as auranofin's target [39].

The cyclam derivative AMD3100 was found to promote a reduction of X4 HIV-1 levels in HIV-infected individuals during phase I/II clinical trials. During phase I pharmacokinetic studies, AMD3100 elevated white blood cell counts, which was later attributed to a remarkable mobilization of hematopoietic progenitor cells, in particular CD34+ stem cells, from the bone marrow into the bloodstream [40]. Meanwhile, it was found that AMD3100 is an extremely specific and effective CXCR4 antagonist. Consequently, AMD3100 was 
found to be efficacious in a variety of disorders that depend on the interplay of CXCR4 with its natural agonist SDF-1. These results opened the potential clinical use of AMD3100 (and its congeners) to the treatment of HIV infections as well as rheumatoid, allergic, and malignant diseases and, in principle, many other diseases that would profit from stem cell mobilization [41]. More recently, cyclam derivatives were found to be also active against a variety of Gram-positive and Gram-negative bacterial strains. Cyclams bearing substituted triazole moieties revealed a good potency against some Mycobacterium strains, with MIC values in the low micromolar range $(3.13-6.25 \mu \mathrm{M})$. The trans-disubstituted cyclam with naphthalimide groups in the triazole moieties displays high activity against Mycobacterium avium, Mycobacterium bovis, and M. tuberculosis [42,43]. Replacing naphthalimide by naphthyl or benzyl groups led to a decrease in the antibacterial activity. Importantly, the inhibitory effect was maintained against clinical isolates of $M$. tuberculosis resistant to single or multiple antimycobacterial drugs, most notably strains resistant to isoniazid, rifampicin, and ethambutol. A series of trans-disubstituted cyclams displaying benzyl groups directly attached to the cyclam ring was also found to be active against E. coli and S. aureus $[44,45]$. These results revealed that the presence of a $\mathrm{CF}_{3}$ moiety in the benzyl groups is crucial for the antibacterial activity of the compounds. The effect of the substitution pattern revealed that changing the $\mathrm{CF}_{3}$ moiety from the para to the meta position in the benzyl groups led to an increase in the MIC values. The same trend was observed when a $\mathrm{CH}_{2}$ spacer was introduced between the $\mathrm{CF}_{3}$ moiety and the aromatic ring. Replacing a $\mathrm{CF}_{3}$ with a $\mathrm{CH}_{3}$ moiety led to a drastic decrease in the activity of the compound against both bacterial strains. These results suggested that the position and the polarity of the substituent on the benzyl groups attached to the cyclam ring are crucial for the antimicrobial activity of the compounds. A neamine cyclam derivative (NeaCyclam) was revealed to be highly effective against E. coli and Enterobacter aerogenes [46]. It is noteworthy that MIC values in the range of 4-16 $\mathrm{gg} / \mathrm{mL}$ obtained for the resistant clinical strain E. aerogenes EA289 (a clinical MDR strain that overexpresses the AcrAB-TolC efflux pump) were lower than those obtained for common antibiotics belonging to $\beta$-lactams, quinolones, and phenicol families (MICs $>128 \mu \mathrm{g} / \mathrm{mL}$ ). This compound was found to affect the outer membrane stability by altering the permeability barrier.

Antipsychotics, antidepressants, antiplatelets, antifungals, and drugs for the treatment of multiple sclerosis are other drugs showing antimicrobial activity against bacterial pathogens. Table 1 summarizes drugs that have shown antimicrobial activity towards MDR bacteria and are, therefore, potential candidates to be repurposed as antibiotics.

Table 1. "Nonantibiotic" approved drugs with antimicrobial activity towards MDR bacteria.

\begin{tabular}{|c|c|c|c|c|}
\hline Drug & $\begin{array}{l}\text { Primary Medical } \\
\text { Indication }\end{array}$ & Antimicrobial Activity & Mechanism of Action & Reference \\
\hline Mitomycin C & Anticancer & E. coli, S. aureus, $P$. aeruginosa & Crosslinking DNA. Eradicates cells in biofilms. & [26] \\
\hline Cisplatin & Anticancer & E. coli, S. aureus, P. aeruginosa & $\begin{array}{l}\text { Crosslinking DNA. } \\
\text { Effective against biofilm and planktonic cells of } \\
\text { P. aeruginosa. }\end{array}$ & [27] \\
\hline Gallium & Anticancer & $\begin{array}{l}\text { P. aeruginosa (CF patients } \\
\text { isolates), K. pneumoniae, } \\
\text { A. baumannii }\end{array}$ & $\begin{array}{l}\text { P. aeruginosa: Disrupts iron metabolism and } \\
\text { increases oxidant sensitivity. } \\
\text { K. pneumoniae: reduces CFUs and biofilm. } \\
\text { A. baumannii: disrupts the iron metabolism. }\end{array}$ & {$[28-30]$} \\
\hline $\begin{array}{l}\text { 5-fluoro- } 2^{\prime}- \\
\text { deoxyuridine }\end{array}$ & Anticancer & $\begin{array}{l}\text { MRSA, VRSA, MSSA, VISA, } \\
\text { E. faecium; Enterecoccus faecalis }\end{array}$ & $\begin{array}{l}\text { Inhibits thymidylate synthase and impairs nucleic } \\
\text { acids' metabolism and structure. }\end{array}$ & [47] \\
\hline Curcumin & Anticancer & P. aeruginosa, S. aureus & $\begin{array}{l}\text { Causes nucleic acid and protein leakage, indicating } \\
\text { impairment of the membrane. }\end{array}$ & [48] \\
\hline Simvastatin & Statin & MSSA, MRSA, VRE, VSE & $\begin{array}{l}\text { Targets HMG-CoA reductase in eukaryotes. } \\
\text { However, no mechanism described for prokaryotes. }\end{array}$ & {$[31]$} \\
\hline Niclosamide & Anthelmintic & P. aeruginosa & $\begin{array}{l}\text { Inhibits the QS response and the production of } \\
\text { acyl-homoserine lactone signal molecules. } \\
\text { Inhibits the transcription of genes related to } \\
\text { adhesion and biofilm formation. }\end{array}$ & {$[32]$} \\
\hline
\end{tabular}


Table 1. Cont.

\begin{tabular}{|c|c|c|c|c|}
\hline Drug & $\begin{array}{l}\text { Primary Medical } \\
\text { Indication }\end{array}$ & Antimicrobial Activity & Mechanism of Action & Reference \\
\hline Terfenadine & Antihistamine & S. aureus, E. faecium, E. faecalis & $\begin{array}{l}\text { Type II topoisomerase inhibitor. Targets both DNA } \\
\text { gyrase and topoisomerase IV. Antimicrobial activity } \\
\text { against planktonic, biofilm and small-colony } \\
\text { variant (scv) forms of } S \text {. aureus. }\end{array}$ & [33] \\
\hline Verteporfin & Photosensitizer & S. aureus & $\begin{array}{l}\text { Inhibits the GraXRS-dependent promoter. } \\
\text { Sensitizes bacteria against PMN cells. }\end{array}$ & {$[34]$} \\
\hline Lidocaine & Anesthetic & P. aeruginosa, E. coli, S. aureus & No mechanism described. & {$[35]$} \\
\hline Prilocaine & Anesthetic & P. aeruginosa, E. coli, S. aureus & No mechanism described. & {$[35]$} \\
\hline Bupivacaine & Anesthetic & MRSA, S. aureus, E. coli & No mechanism described. & [36] \\
\hline Pethidine & Opioid & $\begin{array}{l}\text { MRSA, S. aureus, E. coli, } \\
\text { P. aeruginosa }\end{array}$ & No mechanism described. & {$[36]$} \\
\hline Penfluridol & Antipsychotic & E. faecalis & $\begin{array}{l}\text { Eradicates biofilm, probably inhibiting the QS } \\
\text { system and the second messenger c-di-GMP. }\end{array}$ & [49] \\
\hline Thioridazine & Antipsychotic & MRSA, Enterococcus species & $\begin{array}{l}\text { MRSA: Inhibits bacterial efflux pumps. Inhibits } \\
\text { replication of phagocytosed MRSA or causing } \\
\text { ultrastructural changes in the cell envelope and } \\
\text { consequent lysis after phagocytosis. }\end{array}$ & {$[50]$} \\
\hline Sertraline & Antidepressant & S. aureus, E. coli, P. aeruginosa & $\begin{array}{l}\text { Hypothesized to inhibit efflux pumps in bacteria } \\
\text { once it is a serotonin reuptake inhibitor in humans. } \\
\text { However, further studies are required. }\end{array}$ & {$[51]$} \\
\hline Ebselen & $\begin{array}{l}\text { Anti-inflammatory, } \\
\text { antioxidative and } \\
\text { antiatherosclerotic } \\
\text { (safety proven, but not } \\
\text { clinically used) }\end{array}$ & $\begin{array}{l}\text { MRSA, VRSA, MSSA, VISA, } \\
\text { E. coli, E. faecium, E. fecalis }\end{array}$ & Inhibits the TrxR system. & {$[47,52]$} \\
\hline Ibuprofen & Anti-inflammatory & $\begin{array}{l}\text { P. aeruginosa, Burkholderia } \\
\text { species, E. faecalis }\end{array}$ & $\begin{array}{l}\text { Suggested to uncouple oxidative phosphorylation } \\
\text { in bacteria, to alter bacterial hydrophobicity, } \\
\text { hemolysin production and inhibit fimbriae. } \\
\text { Reduces biofilm biomass. }\end{array}$ & {$[53,54]$} \\
\hline Diclofenac & Anti-inflammatory & E. faecalis & $\begin{array}{l}\text { Suggested inhibition of bacterial DNA synthesis or } \\
\text { impairment of membrane mechanisms. However, } \\
\text { further studies are required. }\end{array}$ & [54] \\
\hline Ticagrelor & Antiplatelet & MSSA, GISA, MRSA, VRE & Inhibits MRSA and VRE biofilm formation. & [55] \\
\hline Auranofin & Antirheumatic & MRSA, E. faecium, E. faecalis & $\begin{array}{l}\text { MRSA: Downregulates the proteins of } 5 \text { major } \\
\text { biosynthetic pathways (DNA, RNA, protein, } \\
\text { cell-wall, and lipid synthesis). Reduces MRSA } \\
\text { toxins. Eradicates intracellular MRSA in infected } \\
\text { macrophages. } \\
\text { Enterococcus: Antibiofilm activity. Inhibits selenium } \\
\text { metabolism and selenoenzymes. }\end{array}$ & {$[56,57]$} \\
\hline $\begin{array}{l}\text { Glatiramer } \\
\text { acetate }\end{array}$ & Multiple sclerosis & $\begin{array}{l}\text { E. coli, A. baumannii, } \\
\text { P. aeruginosa (CF patients } \\
\text { isolates) }\end{array}$ & Forms intracellular condensates. & {$[58]$} \\
\hline Ciclopirox & Antifungal & $\begin{array}{l}\text { P. aeruginosa, Proteus mirabilis, } \\
\text { E. coli, K. pneumoniae, S. aureus, } \\
\text { Corynebacterium spp., } \\
\text { A. baumannii }\end{array}$ & $\begin{array}{l}\text { Affects LPS composition and galactose metabolism } \\
\text { in E. coli. }\end{array}$ & {$[59,60]$} \\
\hline
\end{tabular}

CF: cystic fibrosis; GISA: glycopeptide intermediate S. aureus.

It is also important to highlight that some of the drugs, besides having direct antimicrobial activity, are also able to enhance the activity of antibiotics when coadministered. This is the case of the antipsychotic penfluridol, which directly inhibited bacteria and still showed partial synergism with amikacin and gentamycin and additive effect with vancomycin and teicoplanin. This combination is expected to reduce both the antibiotic's side effects and the occurrence of antibiotic resistance [49]. Nevertheless, there are drugs (such as the antiparasitic oxyclozanide) that, even with poor or any direct antimicrobial activity, are able to increase the antibiotics efficacy [61]. Anticancer, antidepressant, and 
antiparasitic agents, as well as drugs for the treatment of alcoholism and diarrhea, are also pointed out as potential helper nonantibiotics. A few examples are summarized in Table 2.

Table 2. "Nonantibiotic" approved drugs that synergize with antibiotics towards MDR bacteria.

\begin{tabular}{|c|c|c|c|c|}
\hline Drug & $\begin{array}{l}\text { Primary Medical } \\
\text { Indication }\end{array}$ & Synergy with & Antimicrobial Activity & Reference \\
\hline Gallium & Anticancer & Colistin & A. baumannii & {$[30]$} \\
\hline Curcumin & Anticancer & Ciprofloxacin & P. aeruginosa; S. aureus & [48] \\
\hline Penfluridol & Antipsychotic & $\begin{array}{l}\text { Amikacin, GentamycinAdditive effect: } \\
\text { Vancomycin, Teicoplanin }\end{array}$ & E. faecalis & [49] \\
\hline Thioridazine & Antipsychotic & Vancomycin, Ampicillin & Enterococcus species & [50] \\
\hline Sertraline & Antidepressant & $\begin{array}{c}\text { Ciprofloxacin, Norfloxacin, Moxifloxacin, } \\
\text { Gentamicin, Levofloxacin. } \\
\text { Resistance of E. coli to cefexime was } \\
\text { reversed. }\end{array}$ & $\begin{array}{l}\text { S. aureus, E. coli, } \\
\text { P. aeruginosa }\end{array}$ & {$[51]$} \\
\hline $\begin{array}{c}\text { Salicylanilides } \\
\text { (Oxyclozanide, } \\
\text { Rafoxanide, Closantel) }\end{array}$ & $\begin{array}{l}\text { Internal antiparasitic } \\
\text { for veterinary use }\end{array}$ & Colistin & $\begin{array}{c}\text { E. cloacae, A. baumannii, } K . \\
\text { pneumoniae, E. coli, } \\
\text { P. aeruginosa, }\end{array}$ & {$[61]$} \\
\hline Disulfiram & Alcoholism treatment & Minocycline & S. aureus & {$[62]$} \\
\hline Loperamide & Diarrhea treatment & Minocycline & P. aeruginosa; E. coli & {$[62]$} \\
\hline Ticagrelor & Antiplatelet & Rifampicin, Ciprofloxacin and Vancomycin & MRSA & [55] \\
\hline
\end{tabular}

\subsection{Metal-Based Complexes}

Metal complexes became a fundamental pillar in medicinal chemistry after the approval of platinum in chemotherapy. Over the last two decades, metal complexes of titanium, iron, ruthenium, gallium, palladium, silver, gold, bismuth, and copper have reached clinical trials for cancer, malaria, and neurodegenerative diseases treatment [63]. The interest in metal complexes is also rising due to their ability to perform ligand exchange, generating ROS and depleting essential substrates, which is not accessible to organic compounds [63]. The shape of a molecule is one of the key factors in determining its biological fate and activity. Coordination compounds can display a vast variety of geometries and possess a more defined tridimensional arrangement in comparison to organic molecules [63]. Therefore, the structural properties of these molecules can be associated with higher clinical success rates. Lately, this research has been extended to their potential as antimicrobials, and these novel potential compounds were extensively reviewed [63-65]. Herein, the mode of action of silver and gold-based complexes is further described.

The antibacterial activity of silver ions was first described in the 19th century, and colloidal silver was accepted by the FDA as being effective for wound management in the 1920s [66]. However, after the introduction of penicillin in the 1940s, the use of silver diminished. In 1968, silver nitrate was combined with sulfonamide to form silver sulfadiazine, and was started to be used as a broad-spectrum antibacterial cream for the treatment of burns [67]. Silver sulfadiazine was shown to be effective against E. coli, S. aureus, Klebsiella sp., and Pseudomonas sp. It was shown that silver, but not sulfaziadine, was bound by bacteria [67]. The efficacy of silver sulfadiazine is thought to result from its slow and steady reactions with serum and other sodium chloride-containing body fluids, which allows the slow and sustained delivery of silver ions into the wound environment. More recently, clinicians started using wound dressings that incorporate silver as an alternative therapy to resistant bacteria (e.g., MRSA), because of clinical limitations of several first-line antibacterials [68]. In the last 20 years, several studies have also shown the antibacterial properties of several silver complexes against Gram-positive and Gramnegative bacteria [69-71]. One of these new classes are $\mathrm{N}$-heterocyclic carbene (NHC) complexes of silver(I) that revealed interesting antimicrobial activity against resistant respiratory bacterial pathogens, including B. cepacia complex strains [72]. Camphor-based silver complexes have also shown promising antimicrobial properties against bacterial 
pathogens, being more active against Gram-negative bacteria, including P. aeruginosa and Burkholderia contaminans [70,71].

The exact mechanism of action of silver-based complexes on the bacterial pathogen is still not fully understood, however it has been observed to cause morphological and structural changes to bacterial cells [73]. It is suspected that the observed antibacterial effect is caused by the $\mathrm{Ag}(\mathrm{I})$ ions being released through dissociative mechanisms after entering into bacteria as coordination compounds [63]. Silver ions are proposed to react with electron donor groups $(\mathrm{N}, \mathrm{O}$, or $\mathrm{S}$ atoms), which are present in amino, imidazole, phosphate, carboxyl, or thiol groups in proteins and DNA [74]. Therefore, one of the possible mechanisms of action involves the interaction with thiol groups that are found in the respiratory enzymes of bacterial cells, leading to protein inactivation [74]. In the case of E. coli, silver ions interact with the ribosome, causing the inhibition of the expression of proteins essential for ATP production [75].

The antimicrobial activity of gold complexes has been shown to be intrinsically related to the ligands coordinated to the gold center, and not only dependent on the gold content [76]. For that reason, many different types of gold complexes have been synthesized and characterized, and their antimicrobial and cytotoxic activity have been assessed [77]. The main $\mathrm{Au}$ (I) complexes tested for antimicrobial activity contain phosphine (e.g., auranofin) or N-heterocyclic carbene (NHC) ligands [77]. The majority of the Au(I) complexes tested demonstrated selective antibacterial effects towards Gram-positive bacteria. Au(I) phosphine complexes have been gaining interest due to their easy synthesis and purification and the versatility of ligands, which provide many possibilities to rationalize the complex, according to the desired lipophilicity, hydrophilicity, and other parameters [78]. Increased interest in $\mathrm{Au}(\mathrm{I})-\mathrm{NHC}$ complexes are due to the high stability of their coordinated compounds, great versatility of NHC ligands, and potential antimicrobial activity [79]. Some $\mathrm{Au}(\mathrm{I})-\mathrm{NHC}$ complexes have even proved to be more efficient than silver homologues, probably due to the greater stability of the gold-NHC bond and consequent lower vulnerability to biologically active thiol groups [80]. The organic moiety was shown to have a high influence on the antimicrobial properties of the $\mathrm{Au}(\mathrm{I})$ complexes in such a way that small changes in the ligand skeleton can lead to different microbial responses [81]. Dogan et al. also observed that the antimicrobial activity might be influenced by the type of functional group bounded to the ligand [82]. Eiter et al. have shown that another important factor to consider is the charge of the complex, observing that the +1 -charged complexes had better antimicrobial activity than the +2 -charged complexes, which consequently had higher antimicrobial activity than +3 -charged complexes [83]. However, whether these differences came from the cationic charge remains unclear, as the net charge could impair the cross-membrane transport of gold, or result from the reactivity due to the trans-thiourea sulfur bonding [83]. Another group of gold complexes commonly tested regarding their antimicrobial activity are the $\mathrm{Au}$ (III) complexes of general formula (CR)AuX $\mathrm{X}_{2}$, in which CR is a bifunctional ligand, forming a $\mathrm{Au}-\mathrm{C}$ bond, and $\mathrm{X}_{2} \sigma$ represents two unidentate anions or one bidentate anion. Together, these components form a neutral complex with a square planar geometry [84]. Just as for $\mathrm{Au}(\mathrm{I})$ complexes, $\mathrm{Au}(\mathrm{III})$ complexes antimicrobial activity is also influenced by the organic moiety. As shown by Parish et al., different ligands originated in $\mathrm{Au}(\mathrm{III})$ complexes with different antimicrobial activity, when testing $\mathrm{AuCl}_{2}$ (damp) and $\mathrm{AuCl}_{2}$ (ppy) complexes (being damp = 2-((dimethylamino)methyl)-phenyl and ppy $=2$-pyridylphenyl $)$ and observing that the complex with the damp ligand was more active than the complex with the ppy ligand [85]. Moreover, the antimicrobial activity was improved after synthesizing the more watersoluble complex $\mathrm{Au}\left(\mathrm{CH}_{3} \mathrm{COO}\right)_{2}$ (damp), especially against $S$. aureus and E. faecalis [86]. Reduced polarity and higher lipophilicity were also suggested to facilitate the passage of $\mathrm{Au}$ (III) complexes through the lipid bilayer, allowing them to inactivate diverse essential cellular enzymes, and consequently resulting in higher antimicrobial activity [87]. This was observed by comparing the antimicrobial activity of a $\mathrm{Au}(\mathrm{III})$ complex containing a quinolone ligand-a nalidix complex $\left(\left[\mathrm{Au}(\right.\right.$ nix $\left.\left.)(\mathrm{Cl})_{2}\right]\right)$ with the $\mathrm{Ca}(\mathrm{II}), \mathrm{Fe}(\mathrm{III})$, and $\mathrm{Pd}(\mathrm{II})$ 
analog complexes, standard drugs (tetracycline and amphotericin B), and the free ligand [87]. Other gold complexes that were described as displaying remarkable antibacterial activity were the tetrachloroaurate (III) complex $\left[\left(\mathrm{H}_{2}\right.\right.$ thioterpy) $\left.\mathrm{Cl}\left(\mathrm{AuCl}_{4}\right)\right]$ and the bisdithiolate $\mathrm{Au}(\mathrm{III})$ complexes $\left[\mathrm{NBu}_{4}\right]\left[\mathrm{Au}(\mathrm{cdc})_{2}\right]$ (where $\mathrm{cdc}=$ cyanodithioimidocarbonate), $\left[\mathrm{PPh}_{4}\right]\left[\mathrm{Au}(\mathrm{qdt})_{2}\right]$ (where qdt $=$ quinoxaline-2,3-dithiolate), and [NEt 4 ] $\left.\mathrm{Au}(\mathrm{Et} \text {-thiazdt })_{2}\right]$ (where thiazdt $=N$-alkyl-1,3-thiazoline-2-thione dithiolate) [88-90]. The bisdithiolate $\mathrm{Au}(\mathrm{III})$ complexes tested were only active against Gram-positive bacteria.

The thiol-based redox metabolism has been described as particularly vulnerable to gold complexes [38,91]. The metabolism of thiol is essential to mediate the reduction and oxidation of disulfide bonds, performing thiol-disulfide exchange between cysteines included in their active site and cysteines that belong to the substrate protein [92]. This is crucial for the proper function of regulatory processes, protein folding, DNA synthesis, and defense against oxidative stress $[92,93]$. The major antioxidant systems found in bacteria are Trx, glutathione (GSH), and catalase [93]. To put this in context, the thioredoxin system (TrxTrxR) is composed of NADPH, TrxR, and Trx. This system is ubiquitous; however, some bacteria lack the glutathione system (GSH-Grx) and catalase. Most Gram-negative bacteria, such as E. coli, possess the three types of antioxidant systems, and the GSH system acts as a backup when the Trx-TrxR system is compromised [93]. However, in M. tuberculosis and many Gram-positive, and some Gram-negative, bacteria, such as Helicobacter pylori, the glutathione system is absent, meaning that the Trx system is entirely responsible for cellular thiol/disulfide balance and survival under oxidative stress [93]. This is the case of S. aureus, in which Trx-TrxR was experimentally confirmed to be essential for growth [94]. Other bacteria lack catalase, such as many streptococci, being the antioxidant function dependent on a major thiol-dependent system, which remains unclear [93].

Other researchers have found that gold complexes (e.g., auranofin) can cause the inhibition of multiple biosynthetic pathways in S. aureus [57]. When tested in subinhibitory concentrations, auranofin inhibited cell wall and DNA synthesis (although not by intercalation), and when in higher concentrations, auranofin inhibited protein synthesis. The downregulation of five major biosynthetic pathways (lipid, cell wall, protein, RNA, and DNA), and the inhibition of the production of the major S. aureus toxins, Panton-Valentine leucocidin (PVL) and $\alpha$-hemolysin (Hla), were observed upon exposure to auranofin [57].

However, some resistance to gold complexes was observed in some bacterial pathogens. One of the mechanisms underlying resistance was the reduced uptake caused by membrane reduced permeability. This finding was reported by Marzo et al., who proved increased susceptibility when administering auranofin together with a permeabilizing agent, such as polymyxin B [95]. These authors showed that the lack of antibacterial activity of auranofin was due to the lower outer membrane permeability instead of glutathione alone [95]. The presence of efflux pumps was also suggested to be part of the resistance mechanisms of Gram-negative against auranofin, which was confirmed by Thangamani et al. after deleting the efflux pump AcrAB in E. coli and observing a four-fold decrease in the auranofin's minimum inhibitory concentration [57]. Liu et al. compared the antibacterial activity of $\mathrm{Au}(\mathrm{III})$ complexes with their $\mathrm{Au}(\mathrm{I})$ analogues and observed that the $\mathrm{Au}(\mathrm{III})$ complexes were more active against Gram-positive than the $\mathrm{Au}(\mathrm{I})$ analogue [96]. Both had low activity against Gram-negative bacteria.

Trimetallic complexes with $\left\{\mathrm{Pt}_{2} \mathrm{Au}(\mu-\mathrm{S})_{2}\right\}^{\mathrm{n}+}(\mathrm{n}=2,3)$ cores containing $\mathrm{C}, \mathrm{N}$ and $\mathrm{N}$, $\mathrm{N}$ donor ligands were also synthesized and their antimicrobial activity was assessed by White et al. [97]. However, these complexes exhibited a reduced antimicrobial activity when compared to other cycloaurated gold(III) complexes.

\subsection{Antimicrobial Peptides}

Antimicrobial peptides (AMPs), a diverse group of bioactive small proteins, are essential host defense components that are ribosomally synthesized by most lifeforms, including bacteria, archaea, fungi, plants, and animals $[98,99]$. Natural AMPs are usually rich in positively charged amino acid residues (such as lysine, arginine, and histidine), have 
an amphipathic nature, and show a broad spectrum of activity against a wide range of pathogens (bacteria, fungi, parasites, virus) $[100,101]$. Structurally, these peptides are generally divided into four categories (linear $\alpha$-helical, $\beta$-sheet, extended, and cyclic peptides), and their physicochemical properties influence the action mechanism of AMPs. The stereotypical mechanism of AMP action is to integrate into the bacterial cell membrane and disrupt its integrity, leading directly or indirectly to bacterial cell lysis and death $[102,103]$. Although bacterial killing by AMPs commonly occurs via membrane perturbation mechanisms, they can also exhibit more complex activities, including bacterial cell penetration and interference with vital intracellular processes (e.g., metabolic and translation inhibition) [104-106].

In addition to the fast killing kinetics, pharmacodynamic properties, and mechanisms of killing that overcome common resistance mechanisms of MDR pathogens, AMPs may elicit an anti-infective host immune response and possess the ability to neutralize toxins [107-110]. The antibiofilm properties of these molecules may also confer efficacy against infections associated with wounds, medical implants, and chronic respiratory illnesses [111-113].

Considering the critical status of bacterial resistance, several attempts have been made to find AMP-based effective therapeutics. To date, there are numerous clinically relevant AMPs that were reported to show antimicrobial, antibiofilm, anti-inflammatory, and/or wound healing abilities. However, only a few of these peptides have proceeded to preclinical studies or clinical trials, obtained FDA approval, or have been launched on the market.

Due to their antimicrobial potency, nisin, gramicidin, polymyxins, daptomycin, and melittin were approved for clinical use. Nisin, a polycyclic antibacterial peptide naturally produced by lactic acid bacteria, is an FDA-approved and generally regarded as safe (GRAS) peptide that is mostly used in Europe as an antibacterial food additive [114,115]. However, the safety profile, together with the broad-spectrum bactericidal activity, including drug-resistant bacterial strains such as MRSA, Streptococcus pneumoniae, Enterococci, and C. difficile, indicated that the application of nisin could extend beyond food-related bacteria $[115,116]$. Melittin, a small peptide with anti-inflammatory properties, and the main component of the venom of the honeybee Apis mellifera, was approved by the FDA for relieving pain and swelling associated with some inflammatory diseases [117,118]. Similar to nisin, the action of melittin against drug-resistant bacteria in several in vitro and animal experiments suggests that the clinical application of this peptide could be extended beyond the FDA-approved purposes [119,120]. Gramicidin and daptomycin are effective against a variety of Gram-positive bacteria, including antibiotic-resistant strains [121,122]. Daptomycin is intravenously administrated and can be used in combination with $\beta$-lactam, improving the clinical outcomes in patients with MSRA bloodstream infections [123]. Despite its bactericidal, antipersister, and antibiofilm activities towards various relevant clinical strains, gramicidin is only used as a topical agent, especially for ophthalmological purposes, due to its cytotoxicity [124]. Polymyxins are a group of naturally occurring cyclic polypeptides that show activity against MDR Gram-negative bacteria, such as P. aeruginosa and E. coli, their main target being the lipopolysaccharide [125]. Polymyxin B, usually prescribed to treat eye infections, and polymyxin E (colistin), used to treat wound infections, are crucial and in clinical use; however, due to their severe toxicity, they are reserved as lastresort treatment options [126,127]. Polymyxins consist of a cyclic heptapeptide core, which is linked to a pendant acyl long chain bridging through an exocyclic linear tripeptide moiety, and these are important structural features required for showing antibacterial activity. Additionally, positive charge provided by the cationic amino acid residue di-amino butyric acid and a significant hydrophobicity due to the amino acids phenylalanine and leucine play an essential role in their effectiveness. Cyclam-based derivatives have been designed to mimic this class of antibiotics [128]. The cyclic molecular backbone was mimicked by the incorporation of cyclam, and the lipophilicity was promoted by conjugating different long-chain fatty acids. Phenylalanine and leucine were also introduced in the structure. 
The results revealed that longer aliphatic chains led to an increase in the antibacterial activity against $A$. baumannii, P. aeruginosa, E. coli, and K. pneumoniae [128]. The most active compound showed a potent activity in the concentration range of $2-8 \mu \mathrm{g} / \mathrm{mL}$ to both wild-type and drug-resistant clinical isolates of those bacteria. The compound was found to be also highly active against MRSA, with a MIC value of $2 \mu \mathrm{g} / \mathrm{mL}$. The ex vivo antibacterial activity against $P$. aeruginosa ATCC 27853 and $P$. aeruginosa L-2026/17 portrayed its effectivity in the treatment of a human corneal infection model by reducing the bacterial burden by $1.5 \log$ for P. aeruginosa ATCC 27853 and by $1.9 \log$ for the drug-resistant clinical isolate obtained from an ocular infected eye [128].

Based on promising preclinical results showing successful broad-spectrum bacterial activities in in vitro and in vivo models, numerous AMPs have been investigated in human clinical trials, but the low number of AMPs approved for clinical use is discouraging. Omiganan, pexiganan, surotomycin, and Neuprex, which have completed advanced clinical trials, failed in phase III because they did not show the expected effectiveness $[129,130]$. Other trials were not successful because of the increased mortality in treatment groups versus control group (such as in the case of talactoferrin [131]) or the increased toxicity observed in the treated group. Murepavadin is an example of a cyclic peptide specifically potent against $P$. aeruginosa-associated nosocomial pneumonia, whose phase III clinical trial was prematurely ended due to acute renal toxicity in the treated group [132].

Amongst the challenges that hamper the in vivo efficacy of AMPs and delay their successful development for clinical use are (A) the potential loss of activity in the presence of low $\mathrm{pH}$, saline, divalent cations, and serum or plasma proteins; (B) liability to degradation by tissue proteases; (C) potential hemolytic and/or cytotoxic effects; (D) potential immunogenicity and unclear pharmacokinetic properties; (E) low antimicrobial activity in clinically relevant environments, which is particularly important in the context of sepsis as a complication of MDR-associated wound infections; and (F) potential resistance to AMPs, although far less common than resistance to current antibiotics $[133,134]$. Several strategies have been developed to overcome the mentioned limitations and reduce the production costs of AMPs. Ultra-short and/or truncated AMPs, such as LTX-109, a synthetic tripeptide with low propensity for resistance development that can prevent infections by MSSA/MRSA during hospitalization [135], have been pursued by several companies to reduce the production costs.

The development of novel delivery approaches to administer the peptides and the introduction of chemical modifications have been also used to improve their bioavailability and efficacy in vivo. Strategies in the design of modern AMP-polymer surfaces have been optimized, and different nanocarriers (such as novel polymeric and lipidic nanoparticles, carbon nanotubes, micelles, liposomes and cubosomes, polymersomes, microspheres, dendrimers, nanocapsules, and other colloidal delivery systems) have been loaded with AMPs, facilitating the transport and the delivery of these peptides, and offering added value in smart biomedical applications [136]. For instance, to reach the colon and target C. difficile, nisin was encapsulated in pectin/ hydroxypropylmethyl cellulose (HPMC) compression-coated tablets, forming an enzymatically controlled delivery system [137]. E. coli and S. aureus bacterial adhesion was inhibited using the Magainin II peptide covalently immobilized over poly(lactide-co-glycolide) (PLGA) and electrospun PLGA/gelatin fibers [138]. Compared with plain surfactin, gold nanodots comobilized with the AMP surfactin demonstrated a superior antimicrobial activity not only against non-MDR and MDR (including MRSA) bacteria in vitro, but also showed a faster healing and better epithelialization on MRSA-infected wounds in vivo in rats [139]. There is also a wide range of chemical modifications that can be used to improve the stability of AMPs, including the conjugation of different AMPs, the development of synthetic mimics of antimicrobial peptides (SMAMPs), and the use of peptoids, a class of peptidomimetics consisting of $\mathrm{N}$-substituted glycine oligomers. The cationic peptide SA4 and its poly-n-substituted glycin homolog SPO are an example of peptoids that inhibit the planktonic and biofilm formation of A. baumannii strains, which are recognized to be among the most difficult to 
control and treat antimicrobial-resistant Gram-negative bacilli [140]. It was also reported that the hybrid peptide PA2-GNU7, constructed by the addition of PA2 to GNU7, has a high activity and specificity to P. aeruginosa [141]. Interestingly, the chimeric peptides KG18 and VR18, conjugated with tungsten disulfide quantum dots, also showed antibacterial and antibiofilm activity against $P$. aeruginosa [142].

Combination therapies have also been explored to improve the clinical outcomes of antibacterial treatments. The synergism between AMPs and conventional antibiotics, or among different AMPs, have also been investigated, and some favorable results have been documented. For instance, the combination of polymyxins with carbapenems or rifampicin suppresses the development of polymyxin resistance [143]. In vitro data suggested that the combination of colistin with anthelmintic salicylanilides could be an effective killing strategy against $A$. baumannii, K. pneumoniae, P. aeruginosa, and E. coli MDR clinical isolates [61] In addition, the synergistic effect of the proline-rich antibacterial peptide A3-APO with colistin was also reported both in in vitro assays and in a K. pneumoniae-infected bacteremia mice model [144]. It seems that the combination therapy may not only improve the efficacy of AMPs, but also reduce their cytotoxic effects and reduce the treatment costs [129].

In summary, AMPs offer a hopeful alternative to conventional therapeutics; however, a thorough understanding of their structure and interaction with bacterial and host cells is still needed to develop a safe, stable, and efficient antimicrobial product.

\subsection{Antisense Antimicrobial Therapeutics}

Antisense RNAs (asRNAs) are ubiquitous in bacteria and are involved in a wide range of functions, from central metabolism to pathogenesis-related mechanisms $[145,146]$. This strategy can be turned to our favor by using synthetic asRNAs to fight pathogens, targeting metabolism and/or antibiotic resistance genes [147]. Antisense therapies are emerging as one of the best alternative strategies over classic antibiotics, promising to greatly reduce the time required to discover new antimicrobials and enabling therapies specific to a target gene and microorganism. However, these therapies are still far from being a common antimicrobial approach, mostly due to the challenge of delivering oligomers to bacterial cells [148].

Antisense oligomers (ASOs) act by binding to target mRNAs with a complementary sequence. This interaction inhibits the mRNA translation into protein through steric blockage and/or through RNase degradation of the ASO/RNA duplex [149]. The first step to make this therapy clinically possible is to chemically modify the ASOs. The modification of ASOs sugar, backbone, nucleobase, and $3^{\prime}$ - and $5^{\prime}$-terminal can improve their stability, avoid nucleases attacks, and preserve target specificity [150]. ASOs modifications are mainly four: phosphorothioates (PS) linkages, locked (bridged) nucleic acids (LNA/BNA), peptide nucleic acids (PNA), and phosphorodiamidate morpholino oligomers (PMO) [148]. ASOs modifications have been recently reviewed by Hegarty and Stewart [151]. To address the impossibility of delivery-free antisense oligomers (ASO) through the cell wall, some strategies using carriers have been developed. Cell-penetrating peptides (CPPs) and diverse nanomaterials are currently the most studied delivery systems to introduce ASOs inside bacteria [151].

Wesolowski et al. developed a PMO conjugated with CPP to target a highly conserved region in the E. coli gyrA gene sequence [152]. The authors have shown that targeting gyr A with a CPP-PNA reduces the viability of some pathogens such as E. faecalis, S. aureus, P. aeruginosa, and S. pneumoniae, as well as of Streptococcus pyogenes. While the CPP used has a bacteriostatic effect, the PMO is bactericidal, and this combination leads to an enhanced microbial effect [152]. In addition, targeting the $S$. pyogenes gyr $A$ can have a synergistic effect when applied alongside levofloxacin, novobiocin, or spectinomycin [153]. Barkowsky et al. tested several CPPs and observed that HIV-1 TAT, Oligolysine (K8), and (RXR)4XB were the most efficient to abolish bacterial growth in vitro [154].

Równicki et al. were able to activate the mazEF and hipBA toxin-antitoxin system of E. coli using a PNA anti-hipBA, observing growth arrest [155]. In another study, with 
PNAs targeting the ftsZ gene in S. aureus, required for cell division, an inhibited growth and decreased gene expression were also observed [156].

The use of ASOs for targeting antibiotic resistance genes is also being widely explored. Oh et al. showed a restored susceptibility to ciprofloxacin and erythromycin by targeting the multidrug efflux pump genes CmeABC of Campylobacter jejuni with PNAs $[157,158]$. Wang et al. have shown that a PNA targeting the mobilized colistin resistance (mcr-1) gene restored E. coli colistin susceptibility [159]. In another work, targeting the outer membrane protein OprM gene of P. aeruginosa with a phosphorothioate oligodeoxynucleotide led to a reduced resistance to multiple antibiotics [160]. It is noteworthy that in this work the authors used, for the first time, anionic liposomes to encapsulate the ASO to promote their internalization. Recently, Al Husseini et al. focused on P. aeruginosa persisters, highly drug-tolerant cells, and were able to eradicate in vitro P. aeruginosa persisters using a PNA anti-mqsR [161].

Encapsulation within liposomes and conjugation with lipids are still being explored as delivery systems. Some of the latest developments include the use of cationic fusogenic liposomes and lipid oligonucleotides to improve the internalization efficacy [162,163]. Kauss et al. reported an effective reduction of the resistance level to ceftriaxone in E. coli cells harboring blaCTX-M-15 by using an oligonucleotide conjugated to a lipid moiety [163].

Bioinformatics is also bringing a boost for antisense therapies, with the facile accelerated specific therapeutic (FAST) platform being the most recent platform to develop antisense therapies to combat MDR bacteria [164]. Aunins et al. used FAST to create PNAs against CRE bacterial genes identified by transcriptomics. These authors observed a potentiated carbapenem efficacy by targeting $h y c A, d s r B$, and bolA in CRE E. coli, whereas targeting $f l h C$ and $y g a C$ conferred added resistance [165]. The use of transcriptomics with highly efficient bioinformatics platforms can be a game changer in fighting MDR bacteria.

Using a mouse model of infection, Geller et al. were pioneers in showing the efficacy of a PMO (at the time without any vehicle) in an animal model. Targeting the essential acpP gene of E. coli, a reduced viability both in culture and in the peritoneum of the infected mice was observed [166]. Recently, Hansen et al. have shown the efficacy of a PNA antiacpP against colistin- and tigecycline-resistant $E$. coli and K. pneumoniae, whereas Castillo et al. reported a synergistic effect of anti-acp $P$ with trimethoprim and polymyxin $B$ against pathogenic E. coli $[167,168]$. Castillo et al. used the CPP (KFF)3K that was shown by others to be crucial for the PNA to cross through the LPS/outer membrane as well as the inner membrane $[167,169]$. The Greenberg Lab group also assessed the effect of a CPP-PMO to target the antibiotic-resistance gene New Delhi metallo- $\beta$-lactamase (NDM-1), resulting in an improved survival (92\%) and reduced systemic bacterial burden when administered concomitantly with meropenem to E. coli CVB-1-infected mice [170]. The same research group also targeted the acpP gene of Acinetobacter lwoffii and A. baumannii. These authors treated a murine pulmonary infection model with an intranasal (RXR)4-AcpP treatment that led to a survival rate of $100 \%$ [171]. Targeting A. baumannii aac $\left(6^{\prime}\right)$-Ib, a gene important for resistance to aminoglycosides, increased the susceptibility to amikacin, an effect already described for E. coli $[172,173]$. An increased survival rate of infected Galleria mellonella with a synergistic treatment was observed [172]. This additive phenomenon was also recently described when targeting $l p x B$, a gene essential for maintaining the structure of the bacterial cell envelope, combined with colistin treatment [174]. Those works are paving the way for a new viable therapeutic approach in dealing with MDR Acinetobacter species.

LNAs targeting $a a c\left(6^{\prime}\right)-I b$ conjugated with different CPPs have shown a wide range of inhibitory effects towards K. pneumoniae JHCK1, A. baumannii A155, and E. coli TOP10 (pNW1), evidencing the particularity of each organism [175-177]. Targeting acpP was also tested for P. aeruginosa, similar to the mentioned Geller et al. experiment with Acinetobacter, but Howard et al. also targeted other essential genes such as $1 p x C$ and rpsJ. Although the target genes are not directly related to antibiotic resistance, an inhibitory effect was observed in vitro and in vivo, which can also be attributed to synergy with antibiotics [178]. Targeting $a c p P$ was also described to inhibit bacterial-induced inflammatory responses 
in CF IB3-1 cells infected by P. aeruginosa PAO1 [179]. An LNA anti-acpP encapsulated in niosomes has also shown some promising results for P. aeruginosa [180]. CPP-PMOs targeting acp $P$ have also shown interesting results for another group of opportunistic lung pathogens, the Bcc group, where a reduced pathogenicity was observed in CGD mice infected with Burkholderia multivorans [181]. Sawyer et al. showed that a CPP-PMO targeting gyr $A$ (an essential gene required for replication) was able to reduce the viability of $S$. aureus in a mouse cutaneous wound infection with a topical application delivery system [182]. Meng et al. also reported the efficacy of a CPP-LNA against S. aureus. Targeting $f t s Z$, which is required for cell division, these authors observed an inhibitory effect in vitro as well as in infected mice, showing a reduced level of ftsZ mRNA and FtsZ protein expression and an increased survival of mice by $60 \%$ [183]. PNAs targeting mec $A$ and ftsZ have been shown to increase susceptibility to oxacillin of MRSA and Staphylococcus pseudintermedius [184]. The use of a PS to target mecA in combination with oxacillin has also been proven to improve survival rate by $30-50 \%$ in S. aureus-infected mice [185]. RNAP primary $\sigma^{70}$ have also been suggested as a good target for developing novel antisense antibiotic to treat severe MRSA infections [186].

Intracellullar pathogens can be even more challenging for antisense therapies since there is an extra membrane to pass through. One of those pathogens is Listeria monocytogenes. Abushahba et al. tested five CPP-PNA conjugates targeting the L. monocytogenes RNA polymerase $\alpha$ subunit $(r p o A)$. The designed conjugates were capable of silencing rpoA and killing the bacteria in pure culture, in infected macrophage cells, as well as in a Caenorhabditis elegans animal model, with (RXR)4XB being the most effective vehicle [187]. Rajasekaran et al. also used a CPP-PNA to target some genes of Brucella suis, a facultative intracellular pathogen responsible for brucellosis. Targeting polA, a DNA polymerase necessary for DNA replication, was the most effective PNA in broth culture, where the PNAs targeting asd and $d n a G$ revealed the higher inhibitory effect in B. suis infecting macrophages [188]. These differences of effectiveness of PNAs from in vitro to in vivo assays highlight the differences of bacteria metabolism in different environments, as well as the importance of using infection models to test the efficacy of this kind of therapeutics.

\section{Conclusions}

Antibiotic resistance emergence in bacterial pathogens is a global threat to public health systems, not only by the eminent inefficacy of antibiotics against these resistant microorganisms, but also by the associated increase of the risk of performing invasive and noninvasive medical treatments and procedures that rely on antibiotics administration to reduce complications.

The screening of reservoirs of existing nonantibiotic drugs is leading to the identification of new antibacterials, having the advantage of reducing the necessary time for the antibacterial drugs to be approved and available in the market. However, drug repurposing will not solve all nosocomial bacterial infections and drug resistance-associated problems. Therefore, novel compounds with antibacterial activity are also required to tackle these difficult-to-treat infections. These new antimicrobials could lead to the identification of new bacterial targets.

An overview on the efforts by several research groups to develop novel antimicrobials evidences a wide diversity of molecules and approaches in use, expected to lead, in the near future, to their introduction in the market. These novel and effective antimicrobials are urgently needed to combat nosocomial infections.

However, the mechanisms of action of the majority of these new compounds are not clear. Omics technologies could be a helpful strategy for the identification of their drug targets and the bacterial mechanisms of resistance [189].

Author Contributions: Conceptualization, S.A.S. and J.H.L.; all authors participated on writingoriginal draft preparation; writing - review and editing, S.A.S., J.H.L., J.R.F. and L.G.A.; supervision, S.A.S. and J.H.L. All authors have read and agreed to the published version of the manuscript. 
Funding: The authors acknowledge financial support from iBB-Institute for Bioengineering and Biosciences through project UIDB/04565/2020 from Fundação para a Ciência e a Tecnologia (FCT).

Acknowledgments: The authors acknowledge FCT for a PhD fellowship to TP (BIOTECnico PhD program; PD/BD/135137/2017). The graphical abstract was created by BioRender.com (Agreement number: HS22QTPLER).

Conflicts of Interest: The authors declare no conflict of interest. The funders had no role in the design of the study; in the collection, analyses, or interpretation of data; in the writing of the manuscript, or in the decision to publish the results.

\section{References}

1. Suetens, C.; Latour, K.; Kärki, T.; Ricchizzi, E.; Kinross, P.; Moro, M.L.; Jans, B.; Hopkins, S.; Hansen, S.; Lyytikäinen, O.; et al. Prevalence of healthcare-associated infections, estimated incidence and composite antimicrobial resistance index in acute care hospitals and long-term care facilities: Results from two european point prevalence surveys, 2016 to 2017. Eurosurveillance 2018, 23, pii1800516. [CrossRef] [PubMed]

2. Maki, D.G.; Crnich, C.J.; Safdar, N. Nosocomial Infection in the Intensive Care Unit. In Critical Care Medicine: Principles of Diagnosis and Management in the Adult; Elsevier Inc.: Amsterdam, The Netherlands, 2008; pp. 1003-1069.

3. World Health Organization. Prevention of Hospital-Acquired Infections A Practical Guide, 2nd ed.; Ducel, G., Fabry, J., Nicolle, L., Eds.; World Health Organization: Geneva, Switzerland, 2002.

4. Stygall, J.; Newman, S. Hospital acquired infection. In Cambridge Handbook of Psychology, Health and Medicine, 2nd ed.; Cambridge University Press: Cambridge, UK, 2014; pp. 736-738.

5. Centers for Disease Control. Antibiotic Resistance Threats in the United States, 2019; U.S. Department of Health and Human Services, CDC: Atlanta, GA, USA, 2019.

6. Ayobami, O.; Willrich, N.; Harder, T.; Okeke, I.N.; Eckmanns, T.; Markwart, R. The incidence and prevalence of hospitalacquired (carbapenem-resistant) Acinetobacter baumannii in Europe, Eastern Mediterranean and Africa: A systematic review and meta-analysis. Emerg. Microbes Infect. 2019, 8, 1747-1759. [CrossRef] [PubMed]

7. Brink, A.J. Epidemiology of carbapenem-resistant Gram-negative infections globally. Curr. Opin. Infect. Dis. 2019, 32, 609-616. [CrossRef]

8. Slimings, C.; Riley, T.V. Antibiotics and healthcare facility-associated Clostridioides difficile infection: Systematic review and meta-analysis 2020 update. J. Antimicrob. Chemother. 2021, 76, 1676-1688. [CrossRef]

9. Spivak, E.S.; Cosgrove, S.E.; Srinivasan, A. Measuring Appropriate Antimicrobial Use: Attempts at Opening the Black Box. Clin. Infect. Dis. 2016, 63, 1-6.

10. Holmes, A.H.; Moore, L.S.P.; Sundsfjord, A.; Steinbakk, M.; Regmi, S.; Karkey, A.; Guerin, P.J.; Piddock, L.J.V. Understanding the mechanisms and drivers of antimicrobial resistance. Lancet 2016, 387, 176-187. [CrossRef]

11. Theriot, C.M.; Young, V.B. Interactions between the Gastrointestinal Microbiome and Clostridium difficile. Annu. Rev. Microbiol. 2015, 69, 445-461. [CrossRef] [PubMed]

12. Monnet, D.L.; Harbarth, S. Will coronavirus disease (COVID-19) have an impact on antimicrobial resistance? Eurosurveillance 2020, 25, 1-6. [CrossRef]

13. Rawson, T.M.; Moore, L.S.P.; Castro-Sanchez, E.; Charani, E.; Davies, F.; Satta, G.; Ellington, M.J.; Holmes, A.H. COVID-19 and the potential long-term impact on antimicrobial resistance. J. Antimicrob. Chemother. 2020, 75, 1681-1684. [CrossRef]

14. Singh, S.B.; Young, K.; Silver, L.L. What is an "ideal" antibiotic? Discovery challenges and path forward. Biochem. Pharmacol. 2017, 133, 63-73. [CrossRef]

15. Kaye, K.S.; Fraimow, H.S.; Abrutyn, E. Pathogens resistant to antimicrobial agents: Epidemiology, molecular mechanisms, and clinical management. Infect. Dis. Clin. N. Am. 2000, 14, 293-319. [CrossRef]

16. Peterson, E.; Kaur, P. Antibiotic resistance mechanisms in bacteria: Relationships between resistance determinants of antibiotic producers, environmental bacteria, and clinical pathogens. Front. Microbiol. 2018, 9, 2928. [CrossRef]

17. Blair, J.M.A.; Webber, M.A.; Baylay, A.J.; Ogbolu, D.O.; Piddock, L.J.V. Molecular mechanisms of antibiotic resistance. Nat. Rev. Microbiol. 2015, 13, 42-51. [CrossRef]

18. Rice, L.B. Progress and Challenges in Implementing the Research on ESKAPE Pathogens. Infect. Control Hosp. Epidemiol. 2010, 31, S7-S10. [CrossRef]

19. Ashburn, T.T.; Thor, K.B. Drug repositioning: Identifying and developing new uses for existing drugs. Nat. Rev. Drug Discov. 2004, 3, 673-683. [CrossRef]

20. Singh, D.; Jain, S.; Adhaulia, G.; Barua, S.; Sachan, A.K. Drug repositioning: Achievements, advancements and barriers. IP Int. J. Compr. Adv. Pharmacol. 2019, 4, 11-16. [CrossRef]

21. Jourdan, J.P.; Bureau, R.; Rochais, C.; Dallemagne, P. Drug repositioning: A brief overview. J. Pharm. Pharmacol. 2020, 72, 1145-1151. [CrossRef] [PubMed]

22. Sleigh, S.H.; Barton, C.L. Repurposing strategies for therapeutics. Pharm. Med. 2010, 24, 151-159. [CrossRef]

23. Mazumdar, K.; Asok Kumar, K.; Dutta, N.K. Potential role of the cardiovascular non-antibiotic (helper compound) amlodipine in the treatment of microbial infections: Scope and hope for the future. Int. J. Antimicrob. Agents 2010, 36, 295-302. [CrossRef] 
24. Lagadinou, M.; Onisor, M.O.; Rigas, A.; Musetescu, D.V.; Gkentzi, D.; Assimakopoulos, S.F.; Panos, G.; Marangos, M. Antimicrobial properties on non-antibiotic drugs in the era of increased bacterial resistance. Antibiotics 2020, 9, 107. [CrossRef]

25. Soo, V.; Kwan, B.; Quezada, H.; Castillo-Juárez, I.; Pérez-Eretza, B.; García-Contreras, S.; Martínez-Vázquez, M.; Wood, T.; García-Contreras, R. Repurposing of Anticancer Drugs for the Treatment of Bacterial Infections. Curr. Top. Med. Chem. 2016, 17, 1157-1176. [CrossRef]

26. Kwan, B.W.; Chowdhury, N.; Wood, T.K. Combatting bacterial infections by killing persister cells with mitomycin C. Environ. Microbiol. 2015, 17, 4406-4414. [CrossRef]

27. Chowdhury, N.; Wood, T.L.; Martínez-Vázquez, M.; García-Contreras, R.; Wood, T.K. DNA-crosslinker cisplatin eradicates bacterial persister cells. Biotechnol. Bioeng. 2016, 113, 1984-1992. [CrossRef] [PubMed]

28. Goss, C.H.; Kaneko, Y.; Khuu, L.; Anderson, G.D.; Ravishankar, S.; Aitken, M.L.; Lechtzin, N.; Zhou, G.; Czyz, D.M.; McLean, K.; et al. Gallium disrupts bacterial iron metabolism and has therapeutic effects in mice and humans with lung infections. Sci. Transl. Med. 2018, 10, eaat7520. [CrossRef]

29. Thompson, M.G.; Truong-Le, V.; Alamneh, Y.A.; Black, C.C.; Anderl, J.; Honnold, C.L.; Pavlicek, R.L.; Abu-Taleb, R.; Wise, M.C.; Hall, E.R.; et al. Evaluation of gallium citrate formulations against a multidrug-resistant strain of Klebsiella pneumoniae in a murine wound model of infection. Antimicrob. Agents Chemother. 2015, 59, 6484-6493. [CrossRef]

30. Antunes, L.C.S.; Imperi, F.; Minandri, F.; Visca, P. In Vitro and In Vivo antimicrobial activities of gallium nitrate against multidrug-resistant acinetobacter baumannii. Antimicrob. Agents Chemother. 2012, 56, 5961-5970. [CrossRef]

31. Jerwood, S.; Cohen, J. Unexpected antimicrobial effect of statins. J. Antimicrob. Chemother. 2008, 61, 362-364. [CrossRef]

32. Imperi, F.; Massai, F.; Pillai, C.R.; Longo, F.; Zennaro, E.; Rampioni, G.; Visc, P.; Leoni, L. New life for an old Drug: The anthelmintic drug niclosamide inhibits pseudomonas aeruginosa quorum sensing. Antimicrob. Agents Chemother. 2013, 57, 996-1005. [CrossRef] [PubMed]

33. Perlmutter, J.I.; Forbes, L.T.; Krysan, D.J.; Ebsworth-Mojica, K.; Colquhoun, J.M.; Wang, J.L.; Dunman, P.M.; Flaherty, D.P. Repurposing the antihistamine terfenadine for antimicrobial activity against staphylococcus aureus. J. Med. Chem. 2014, 57, 8540-8562. [CrossRef] [PubMed]

34. Prieto, J.M.; Rapún-Araiz, B.; Gil, C.; Penadés, J.R.; Lasa, I.; Latasa, C. Inhibiting the two-component system GraXRS with verteporfin to combat Staphylococcus aureus infections. Sci. Rep. 2020, 10, 1-12. [CrossRef]

35. Aydin, O.N.; Eyigor, M.; Aydin, N. Antimicrobial activity of ropivacaine and other local anaesthetics. Eur. J. Anaesthesiol. 2001, 18, 687-694. [CrossRef] [PubMed]

36. Grimmond, T.R.; Brownridge, P. Antimicrobial activity of bupivacaine and pethidine. Anaesth. Intensive Care 1986, 14, 418-420. [CrossRef]

37. Roder, C.; Thomson, M.J. Auranofin: Repurposing an old drug for a golden new age. Drugs RED. 2015, 15, 13-20.

38. Harbut, M.B.; Vilchèze, C.; Luo, X.; Hensler, M.E.; Guo, H.; Yang, B.; Chatterjee, A.K.; Nizet, V.; Jacobs, W.R.; Schultz, P.G.; et al. Auranofin exerts broad-spectrum bactericidal activities by targeting thiol-redox homeostasis. Proc. Natl. Acad. Sci. USA 2015, 112, 4453-4458. [CrossRef]

39. Fuchs, B.B.; Rajamuthiah, R.; Souza, A.C.R.; Eatemadpour, S.; Rossoni, R.D.; Santos, D.A.; Junqueira, J.C.; Rice, L.B.; Mylonakis, E. Inhibition of bacterial and fungal pathogens by the orphaned drug auranofin. Future Med. Chem. 2016, 8, 117-132. [CrossRef]

40. De Clercq, E. AMD3100/CXCR4 inhibitor. Front. Immunol. 2015, 6, 276. [CrossRef]

41. De Clercq, E. The bicyclam AMD3100 story. Nat. Rev. Drug Discov. 2003, 2, 581-587. [CrossRef] [PubMed]

42. Yu, M.; Nagalingam, G.; Ellis, S.; Martinez, E.; Sintchenko, V.; Spain, M.; Rutledge, P.J.; Todd, M.H.; Triccas, J.A. Nontoxic Metal-Cyclam Complexes, a New Class of Compounds with Potency against Drug-Resistant Mycobacterium tuberculosis. J. Med. Chem. 2016, 59, 5917-5921. [CrossRef]

43. Spain, M.; Wong, J.K.H.; Nagalingam, G.; Batten, J.M.; Hortle, E.; Oehlers, S.H.; Jiang, X.F.; Murage, H.E.; Orford, J.T.; Crisologo, P.; et al. Antitubercular Bis-Substituted Cyclam Derivatives: Structure-Activity Relationships and In Vivo Studies. J. Med. Chem. 2018, 61, 3595-3608. [CrossRef]

44. Alves, L.G.; Pinheiro, P.F.; Feliciano, J.R.; Dâmaso, D.P.; Leitão, J.H.; Martins, A.M. Synthesis, antimicrobial activity and toxicity to nematodes of cyclam derivatives. Int. J. Antimicrob. Agents 2017, 49, 646-649. [CrossRef] [PubMed]

45. Alves, L.G.; Portel, J.F.; Sousa, S.A.; Ferreira, O.; Almada, S.; Silva, E.R.; Martins, A.M.; Leitão, J.H. Investigations into the structure/antibacterial activity relationships of cyclam and cyclen derivatives. Antibiotics 2019, 8, 224. [CrossRef]

46. Allam, A.; Maigre, L.; Alves de Sousa, R.; Dumont, E.; Vergalli, J.; Pagès, J.M.; Artaud, I. New amphiphilic neamine conjugates bearing a metal binding motif active against MDR E. aerogenes Gram-negative bacteria. Eur. J. Med. Chem. 2017, 127, 748-756. [CrossRef]

47. Younis, W.; Thangamani, S.; Seleem, M. Repurposing Non-Antimicrobial Drugs and Clinical Molecules to Treat Bacterial Infections. Curr. Pharm. Des. 2015, 21, 4106-4111. [CrossRef]

48. Kamurai, B.; Mombeshora, M.; Mukanganyama, S. Repurposing of Drugs for Antibacterial Activities on Selected ESKAPE Bacteria Staphylococcus aureus and Pseudomonas aeruginosa. Int. J. Microbiol. 2020, 2020, 8885338. [CrossRef] [PubMed]

49. Zeng, X.; She, P.; Zhou, L.; Li, S.; Hussain, Z.; Chen, L.; Wu, Y. Drug repurposing: Antimicrobial and antibiofilm effects of penfluridol against Enterococcus faecalis. Microbiologyopen 2021, 10, e1148. [CrossRef]

50. Thanacoody, H.K.R. Thioridazine: Resurrection as an antimicrobial agent? Br. J. Clin. Pharmacol. 2007, 64, 566-574. [CrossRef] [PubMed] 
51. Ayaz, M.; Subhan, F.; Ahmed, J.; Khan, A.; Ullah, F.; Ullah, I.; Ali, G.; Syed, N.-H.; Hussain, S. Sertraline enhances the activity of antimicrobial agents against pathogens of clinical relevance. J. Biol. Res. 2015, 22, 1-8. [CrossRef]

52. May, H.C.; Yu, J.J.; Guentzel, M.N.; Chambers, J.P.; Cap, A.P.; Arulanandam, B.P. Repurposing auranofin, ebselen, and PX-12 as antimicrobial agents targeting the thioredoxin system. Front. Microbiol. 2018, 9, 336. [CrossRef]

53. Shah, P.N.; Marshall-Batty, K.R.; Smolen, J.A.; Tagaev, J.A.; Chen, Q.; Rodesney, C.A.; Le, H.H.; Gordon, V.D.; Greenberg, D.E.; Cannon, C.L. Antimicrobial activity of ibuprofen against cystic fibrosis-associated gram-negative pathogens. Antimicrob. Agents Chemother. 2018, 62, e01574-17. [CrossRef]

54. Salem-Milani, A.; Balaei-Gajan, E.; Rahimi, S.; Moosavi, Z.; Abdollahi, A.; Zakeri-Milani, P.; Bolourian, M. Antibacterial Effect of Diclofenac Sodium on Enterococcus faecalis. J. Dent. 2013, 10, 16-22.

55. Lancellotti, P.; Musumeci, L.; Jacques, N.; Servais, L.; Goffin, E.; Pirotte, B.; Oury, C. Antibacterial Activity of Ticagrelor in Conventional Antiplatelet Dosages Against Antibiotic-Resistant Gram-Positive Bacteria. JAMA Cardiol. 2019, 4, 596-599. [CrossRef]

56. AbdelKhalek, A.; Abutaleb, N.S.; Elmagarmid, K.A.; Seleem, M.N. Repurposing auranofin as an intestinal decolonizing agent for vancomycin-resistant enterococci. Sci. Rep. 2018, 8, 8353. [CrossRef]

57. Thangamani, S.; Mohammad, H.; Abushahba, M.F.N.; Sobreira, T.J.P.; Hedrick, V.E.; Paul, L.N.; Seleem, M.N. Antibacterial activity and mechanism of action of auranofin against multi-drug resistant bacterial pathogens. Sci. Rep. 2016, 6, 22571. [CrossRef]

58. Christiansen, S.H.; Murphy, R.A.; Juul-Madsen, K.; Fredborg, M.; Hvam, M.L.; Axelgaard, E.; Skovdal, S.M.; Meyer, R.L.; Sørensen, U.B.S.; Möller, A.; et al. The Immunomodulatory Drug Glatiramer Acetate is Also an Effective Antimicrobial Agent that Kills Gram-negative Bacteria. Sci. Rep. 2017, 7, 1-16. [CrossRef] [PubMed]

59. Gupta, A.K.; Plott, T. Ciclopirox: A broad-spectrum antifungal with antibacterial and anti-inflammatory properties. Int. J. Dermatol. 2004, 43, 3-8. [CrossRef]

60. Carlson-Banning, K.M.; Chou, A.; Liu, Z.; Hamill, R.J.; Song, Y.; Zechiedrich, L. Toward Repurposing Ciclopirox as an Antibiotic against Drug-Resistant Acinetobacter baumannii, Escherichia coli, and Klebsiella pneumoniae. PLoS ONE 2013, 8, 69646. [CrossRef]

61. Domalaon, R.; Okunnu, O.; Zhanel, G.G.; Schweizer, F. Synergistic combinations of anthelmintic salicylanilides oxyclozanide, rafoxanide, and closantel with colistin eradicates multidrug-resistant colistin-resistant Gram-negative bacilli. J. Antibiot. 2019, 72, 605-616. [CrossRef]

62. Ejim, L.; Farha, M.A.; Falconer, S.B.; Wildenhain, J.; Coombes, B.K.; Tyers, M.; Brown, E.D.; Wright, G.D. Combinations of antibiotics and nonantibiotic drugs enhance antimicrobial efficacy. Nat. Chem. Biol. 2011, 7, 348-350. [CrossRef] [PubMed]

63. Frei, A.; Zuegg, J.; Elliott, A.G.; Baker, M.; Braese, S.; Brown, C.; Chen, F.; Dowson, C.G.; Dujardin, G.; Jung, N.; et al. Metal complexes as a promising source for new antibiotics. Chem. Sci. 2020, 11, 2627-2639. [CrossRef]

64. Evans, A.; Kavanagh, K.A. Evaluation of metal-based antimicrobial compounds for the treatment of bacterial pathogens. J. Med. Microbiol. 2021, 70, 001363. [CrossRef]

65. Claudel, M.; Schwarte, J.V.; Fromm, K.M. New Antimicrobial Strategies Based on Metal Complexes. Chemistry 2020, 2, 849-899. [CrossRef]

66. Klasen, H.J. Historical review of the use of silver in the treatment of burns. I. Early uses. Burns 2000, 26, 117-130. [CrossRef]

67. Fox, C.L.; Modak, S.M. Mechanism of silver sulfadiazine action on burn wound infections. Antimicrob. Agents Chemother. 1974, 5, 582-588. [CrossRef]

68. Yeo, E.D.; Yoon, S.A.; Oh, S.R.; Choi, Y.S.; Lee, Y.K. Degree of the hazards of silver-containing dressings on MRSA-Infected wounds in sprague-dawley and streptozotocin-induced diabetic rats. Wounds 2015, 27, 95-102. [PubMed]

69. Nunes, J.H.B.; De Paiva, R.E.F.; Cuin, A.; Da Costa Ferreira, A.M.; Lustri, W.R.; Corbi, P.P. Synthesis, spectroscopic characterization, crystallographic studies and antibacterial assays of new copper(II) complexes with sulfathiazole and nimesulide. J. Mol. Struct. 2016, 1112, 14-20. [CrossRef]

70. Carvalho, M.F.N.N.; Leite, S.; Costa, J.P.; Galvão, A.M.; Leitão, J.H. Ag(I) camphor complexes: Antimicrobial activity by design. J. Inorg. Biochem. 2019, 199, 110791. [CrossRef] [PubMed]

71. Costa, J.P.; Sousa, S.A.; Galvão, A.M.; Miguel Mata, J.; Leitão, J.H.; Carvalho, M.F.N.N. Key parameters on the antibacterial activity of silver camphor complexes. Antibiotics 2021, 10, 135. [CrossRef]

72. Kascatan-Nebioglu, A.; Panzner, M.J.; Tessier, C.A.; Cannon, C.L.; Youngs, W.J. N-Heterocyclic carbene-silver complexes: A new class of antibiotics. Coord. Chem. Rev. 2007, 251, 884-895. [CrossRef]

73. Woo, K.J.; Hye, C.K.; Ki, W.K.; Shin, S.; So, H.K.; Yong, H.P. Antibacterial activity and mechanism of action of the silver ion in Staphylococcus aureus and Escherichia coli. Appl. Environ. Microbiol. 2008, 74, 2171-2178.

74. Gordon, O.; Slenters, T.V.; Brunetto, P.S.; Villaruz, A.E.; Sturdevant, D.E.; Otto, M.; Landmann, R.; Fromm, K.M. Silver coordination polymers for prevention of implant infection: Thiol interaction, impact on respiratory chain enzymes, and hydroxyl radical induction. Antimicrob. Agents Chemother. 2010, 54, 4208-4218. [CrossRef]

75. Yamanaka, M.; Hara, K.; Kudo, J. Bactericidal actions of a silver ion solution on Escherichia coli, studied by energy-filtering transmission electron microscopy and proteomic analysis. Appl. Environ. Microbiol. 2005, 71, 7589-7593. [CrossRef]

76. Nomiya, K.; Noguchi, R.; Ohsawa, K.; Tsuda, K.; Oda, M. Synthesis, crystal structure and antimicrobial activities of two isomeric gold(I) complexes with nitrogen-containing heterocycle and triphenylphosphine ligands, $[\mathrm{Au}(\mathrm{L})(\mathrm{PPh} 3)](\mathrm{HL}=\mathrm{pyrazole}$ and imidazole). J. Inorg. Biochem. 2000, 78, 363-370. [CrossRef] 
77. Glišić, B.; Djuran, M.I. Gold complexes as antimicrobial agents: An overview of different biological activities in relation to the oxidation state of the gold ion and the ligand structure. Dalton Trans. 2014, 43, 5950-5969. [CrossRef]

78. Stenger-Smith, J.R.; Mascharak, P.K. Gold Drugs with $\{\mathrm{Au}(\mathrm{PPh} 3)\}+$ Moiety: Advantages and Medicinal Applications. ChemMedChem 2020, 15, 2136-2145. [CrossRef] [PubMed]

79. Hussaini, S.Y.; Haque, R.A.; Razali, M.R. Recent progress in silver(I)-, gold(I)/(III)- and palladium(II)-N-heterocyclic carbene complexes: A review towards biological perspectives. J. Organomet. Chem. 2019, 882, 96-111. [CrossRef]

80. Ray, S.; Mohan, R.; Singh, J.K.; Samantaray, M.K.; Shaikh, M.M.; Panda, D.; Ghosh, P. Anticancer and antimicrobial metallopharmaceutical agents based on palladium, gold, and silver N-heterocyclic carbene complexes. J. Am. Chem. Soc. 2007, 129, 15042-15053. [CrossRef]

81. Novelli, F.; Recine, M.; Sparatore, F.; Juliano, C. Gold(I) complexes as antimicrobial agents. Farmaco 1999, 54, 232-236. [CrossRef]

82. Doğan, Ö.; Kaloğlu, N.; Demir, S.; Özdemir, I.; Günal, S.; Özdemir, I. Synthesis and antimicrobial activity of novel gold(I) N-heterocyclic carbene complexes. Mon. Chem. 2013, 144, 313-319. [CrossRef]

83. Eiter, L.C.; Hall, N.W.; Day, C.S.; Saluta, G.; Kucera, G.L.; Bierbach, U. Gold(I) analogues of a platinum-acridine antitumor agent are only moderately cytotoxic but show potent activity against Mycobacterium tuberculosis. J. Med. Chem. 2009, 52, 6519-6522. [CrossRef] [PubMed]

84. Tiekink, E.R.T. Gold derivatives for the treatment of cancer. Crit. Rev. Oncol. Hematol. 2002, 42, 225-248. [CrossRef]

85. Parish, R.V.; Howe, B.P.; Wright, J.P.; Mack, J.; Pritchard, R.G.; Buckley, R.G.; Elsome, A.M.; Fricker, S.P. Chemical and Biological Studies of Dichloro(2-((dimethylamino)methyl)phenyl)gold(III). Inorg. Chem. 1996, 35, 1659-1666. [CrossRef]

86. Parish, R.V.; Mack, J.; Hargreaves, L.; Wright, J.P.; Buckley, R.G.; Elsome, A.M.; Fricker, S.P.; Theobald, B.R.C. Chemical and biological reactions of diacetato[2-(dimethylaminoniethyl)-phenyl]gold(III), $\left[\mathrm{Au}\left(\mathrm{O}_{2} \mathrm{CMe}\right)_{2}(\mathrm{dmamp})\right]$. J. Chem. Soc. Dalton Trans. 1996, 69-74. [CrossRef]

87. Al-Khodir, F.A.I.; Refat, M.S. Synthesis, structural characterization and biological studies of some nalidixic acid-metal complexes: Metalloantibiotic complexes of some divalent and trivalent metal ions. J. Mol. Struct. 2015, 1094, 22-35. [CrossRef]

88. Sousa, S.A.; Leitão, J.H.; Silva, R.A.L.; Belo, D.; Santos, I.C.; Guerreiro, J.F.; Martins, M.; Fontinha, D.; Prudêncio, M.; Almeida, M.; et al. On the path to gold: Monoanionic Au bisdithiolate complexes with antimicrobial and antitumor activities. J. Inorg. Biochem. 2020, 202, 110904. [CrossRef] [PubMed]

89. Kharat, A.N.; Foroutannejad, S.; Khavasi, H.R. Biological evaluation of 4'-(2-thienyl)-2, 2'; 6' , 2"-terpyridine-1,1"'-diium chloride tetrachloridoaurate (III): The effect of countercations. Synth. React. Inorg. Met. Nano Metal Chem. 2012, 42, 752-757. [CrossRef]

90. Fontinha, D.; Sousa, S.A.; Morais, T.S.; Prudêncio, M.; Leitão, J.H.; Le Gal, Y.; Lorcy, D.; Silva, R.A.L.; Velho, M.F.G.; Velho, M.F.G.; et al. Gold(iii) bis(dithiolene) complexes: From molecular conductors to prospective anticancer, antimicrobial and antiplasmodial agents. Metallomics 2020, 12, 974-987. [CrossRef] [PubMed]

91. Schmidt, C.; Karge, B.; Misgeld, R.; Prokop, A.; Franke, R.; Brönstrup, M.; Ott, I. Gold(I) NHC Complexes: Antiproliferative Activity, Cellular Uptake, Inhibition of Mammalian and Bacterial Thioredoxin Reductases, and Gram-Positive Directed Antibacterial Effects. Chem. A Eur. J. 2017, 23, 1869-1880. [CrossRef] [PubMed]

92. Ritz, D.; Beckwith, J. Roles of thiol-redox pathways in bacteria. Annu. Rev. Microbiol. 2001, 55, 21-48. [CrossRef]

93. Lu, J.; Holmgren, A. The thioredoxin antioxidant system. Free Radic. Biol. Med. 2014, 66, 75-87. [CrossRef]

94. Uziel, O.; Borovok, I.; Schreiber, R.; Cohen, G.; Aharonowitz, Y. Transcriptional Regulation of the Staphylococcus aureus Thioredoxin and Thioredoxin Reductase Genes in Response to Oxygen and Disulfide Stress. J. Bacteriol. 2004, 186, 326-334. [CrossRef]

95. Marzo, T.; Cirri, D.; Pollini, S.; Prato, M.; Fallani, S.; Cassetta, M.I.; Novelli, A.; Rossolini, G.M.; Messori, L. Auranofin and its Analogues Show Potent Antimicrobial Activity against Multidrug-Resistant Pathogens: Structure-Activity Relationships. ChemMedChem 2018, 13, 2448-2454. [CrossRef] [PubMed]

96. Liu, F.; Anis, R.; Hwang, E.; Ovalle, R.; Varela-Ramírez, A.; Aguilera, R.J.; Contel, M. Group 11 metal compounds with tripodal bis(imidazole) thioether ligands. applications as catalysts in the oxidation of alkenes and as antimicrobial agents. Molecules 2011, 16, 6701-6720. [CrossRef] [PubMed]

97. White, B.C.; Henderson, W.; Andy Hor, T.S.; Nicholson, B.K. Synthesis and characterization of new trimetallic complexes with $\left\{\mathrm{Pt}_{2} \mathrm{Au}(\mu-\mathrm{S})_{2}\right\} \mathrm{n}+(\mathrm{n}=2,3)$ cores containing $\mathrm{C}, \mathrm{N}$ and $\mathrm{N}, \mathrm{N}$ donor ligands. Inorg. Chim. Acta 2013, 394, 146-151. [CrossRef]

98. Wuerth, K.; Hancock, R.E.W. New insights into cathelicidin modulation of adaptive immunity. Eur. J. Immunol. 2011, 41, 2817-2819. [CrossRef]

99. Hancock, R.E.W. Cationic peptides: Effectors in innate immunity and novel antimicrobials. Lancet Infect. Dis. 2001, 1, 156-164. [CrossRef]

100. Zasloff, M. Antimicrobial peptides of multicellular organisms. Nature 2002, 415, 389-395. [CrossRef] [PubMed]

101. Beisswenger, C.; Bals, R. Functions of Antimicrobial Peptides in Host Defense and Immunity. Curr. Protein Pept. Sci. 2005, 6, 255-264. [CrossRef]

102. Zhang, L.; Gallo, R.L. Antimicrobial peptides. Curr. Biol. 2016, 26, R14-R19. [CrossRef]

103. Berglund, N.A.; Piggot, T.J.; Jefferies, D.; Sessions, R.B.; Bond, P.J.; Khalid, S. Interaction of the Antimicrobial Peptide Polymyxin B1 with Both Membranes of E. coli: A Molecular Dynamics Study. PLoS Comput. Biol. 2015, 11, e1004180. [CrossRef]

104. Gagnon, M.G.; Roy, R.N.; Lomakin, I.B.; Florin, T.; Mankin, A.S.; Steitz, T.A. Structures of proline-rich peptides bound to the ribosome reveal a common mechanism of protein synthesis inhibition. Nucleic Acids Res. 2016, 44, 2439-2450. [CrossRef] 
105. Florin, T.; Maracci, C.; Graf, M.; Karki, P.; Klepacki, D.; Berninghausen, O.; Beckmann, R.; Vázquez-Laslop, N.; Wilson, D.N.; Rodnina, M.V.; et al. An antimicrobial peptide that inhibits translation by trapping release factors on the ribosome. Nat. Struct. Mol. Biol. 2017, 24, 752-757. [CrossRef] [PubMed]

106. Hale, J.D.F.; Hancock, R.E.W. Alternative mechanisms of action of cationic antimicrobial peptides on bacteria. Expert Rev. Anti Infect. Ther. 2007, 5, 951-959. [CrossRef]

107. Lazzaro, B.P.; Zasloff, M.; Rolff, J. Antimicrobial peptides: Application informed by evolution. Science 2020, 368 , eaau5480. [CrossRef] [PubMed]

108. Friedrich, C.L.; Rozek, A.; Patrzykat, A.; Hancock, R.E.W. Structure and Mechanism of Action of an Indolicidin Peptide Derivative with Improved Activity against Gram-positive Bacteria. J. Biol. Chem. 2001, 276, 24015-24022. [CrossRef]

109. Lin, Q.-P.; Zhou, L.-F.; Li, N.-N.; Chen, Y.-Q.; Li, B.-C.; Cai, Y.-F.; Zhang, S.-Q. Lipopolysaccharide neutralization by the antibacterial peptide CM4. Eur. J. Pharmacol. 2008, 596, 160-165. [CrossRef]

110. Paranjape, S.M.; Lauer, T.W.; Montelaro, R.C.; Mietzner, T.A.; Vij, N. Modulation of proinflammatory activity by the engineered cationic antimicrobial peptide WLBU-2. F1000Research 2013, 2, 36. [CrossRef]

111. Melvin, J.A.; Lashua, L.P.; Kiedrowski, M.R.; Yang, G.; Deslouches, B.; Montelaro, R.C.; Bomberger, J.M. Simultaneous Antibiofilm and Antiviral Activities of an Engineered Antimicrobial Peptide during Virus-Bacterium Coinfection. mSphere 2016, 1, e00083-16. [CrossRef]

112. Lashua, L.P.; Melvin, J.A.; Deslouches, B.; Pilewski, J.M.; Montelaro, R.C.; Bomberger, J.M. Engineered cationic antimicrobial peptide (eCAP) prevents Pseudomonas aeruginosa biofilm growth on airway epithelial cells. J. Antimicrob. Chemother. 2016, 71, 2200-2207. [CrossRef]

113. De Zoysa, G.H.; Cameron, A.J.; Hegde, V.V.; Raghothama, S.; Sarojini, V. Antimicrobial Peptides with Potential for Biofilm Eradication: Synthesis and Structure Activity Relationship Studies of Battacin Peptides. J. Med. Chem. 2015, 58, 625-639. [CrossRef] [PubMed]

114. Cleveland, J.; Montville, T.J.; Nes, I.F.; Chikindas, M.L. Bacteriocins: Safe, natural antimicrobials for food preservation. Int. J. Food Microbiol. 2001, 71, 1-20. [CrossRef]

115. Shin, J.M.; Gwak, J.W.; Kamarajan, P.; Fenno, J.C.; Rickard, A.H.; Kapila, Y.L. Biomedical applications of nisin. J. Appl. Microbiol. 2016, 120, 1449-1465. [CrossRef]

116. Blay, G.L.; Lacroix, C.; Zihler, A.; Fliss, I. In vitro inhibition activity of nisin A, nisin Z, pediocin PA-1 and antibiotics against common intestinal bacteria. Lett. Appl. Microbiol. 2007, 45, 252-257. [CrossRef]

117. Lee, G.; Bae, H. Anti-Inflammatory Applications of Melittin, a Major Component of Bee Venom: Detailed Mechanism of Action and Adverse Effects. Molecules 2016, 21, 616. [CrossRef]

118. Son, D.J.; Lee, J.W.; Lee, Y.H.; Song, H.S.; Lee, C.K.; Hong, J.T. Therapeutic application of anti-arthritis, pain-releasing, and anti-cancer effects of bee venom and its constituent compounds. Pharmacol. Ther. 2007, 115, 246-270. [CrossRef]

119. Choi, J.H.; Jang, A.Y.; Lin, S.; Lim, S.; Kim, D.; Park, K.; Han, S.-M.; Yeo, J.-H.; Seo, H.S. Melittin, a honeybee venom_derived antimicrobial peptide, may target methicillin_resistant Staphylococcus aureus. Mol. Med. Rep. 2015, 12, 6483-6490. [CrossRef] [PubMed]

120. Van den Bogaart, G.; Guzmán, J.V.; Mika, J.T.; Poolman, B. On the mechanism of pore formation by melittin. J. Biol. Chem. 2008, 283, 33854-33857. [CrossRef] [PubMed]

121. David, J.M.; Rajasekaran, A.K. Gramicidin A: A New Mission for an Old Antibiotic. J. Kidney Cancer VHL 2015, 2, 15-24. [CrossRef]

122. Jorgensen, J.H.; Crawford, S.A.; Kelly, C.C.; Patterson, J.E. In vitro activity of daptomycin against vancomycin-resistant enterococci of various Van types and comparison of susceptibility testing methods. Antimicrob. Agents Chemother. 2003, 47, $3760-3763$. [CrossRef] [PubMed]

123. Jorgensen, S.C.J.; Zasowski, E.J.; Trinh, T.D.; Lagnf, A.M.; Bhatia, S.; Sabagha, N.; Abdul-Mutakabbir, J.C.; Alosaimy, S.; Mynatt, R.P.; Davis, S.L.; et al. Daptomycin Plus $\beta$-Lactam Combination Therapy for Methicillin-resistant Staphylococcus aureus Bloodstream Infections: A Retrospective, Comparative Cohort Study. Clin. Infect. Dis. 2020, 71, 1-10. [CrossRef]

124. Berditsch, M.; Afonin, S.; Reuster, J.; Lux, H.; Schkolin, K.; Babii, O.; Radchenko, D.S.; Abdullah, I.; William, N.; Middel, V.; et al. Supreme activity of gramicidin S against resistant, persistent and biofilm cells of staphylococci and enterococci. Sci. Rep. 2019, 9, 17938. [CrossRef] [PubMed]

125. Zavascki, A.P.; Goldani, L.Z.; Li, J.; Nation, R.L. Polymyxin B for the treatment of multidrug-resistant pathogens: A critical review. J. Antimicrob. Chemother. 2007, 60, 1206-1215. [CrossRef] [PubMed]

126. Falagas, M.E.; Kasiakou, S.K. Toxicity of polymyxins: A systematic review of the evidence from old and recent studies. Crit. Care 2006, 10, R27. [CrossRef]

127. Cisneros, J.M.; Rosso-Fernández, C.M.; Roca-Oporto, C.; De Pascale, G.; Jiménez-Jorge, S.; Fernández-Hinojosa, E.; Matthaiou, D.K.; Ramírez, P.; Díaz-Miguel, R.O.; Estella, A.; et al. Colistin versus meropenem in the empirical treatment of ventilatorassociated pneumonia (Magic Bullet study): An investigator-driven, open-label, randomized, noninferiority controlled trial. Crit. Care 2019, 23, 383. [CrossRef]

128. Konai, M.M.; Pakrudheen, I.; Barman, S.; Sharma, N.; Tabbasum, K.; Garg, P.; Haldar, J. Cyclam-based antibacterial molecules eradicate Gram-negative superbugs with potent efficacy against human corneal infection. Chem. Commun. 2020, 56, 2147-2150. [CrossRef] [PubMed] 
129. Magana, M.; Pushpanathan, M.; Santos, A.L.; Leanse, L.; Fernandez, M.; Ioannidis, A.; Giulianotti, M.A.; Apidianakis, Y.; Bradfute, S.; Ferguson, A.L.; et al. The value of antimicrobial peptides in the age of resistance. Lancet Infect. Dis. 2020, 20, e216-e230. [CrossRef]

130. Kosikowska, P.; Lesner, A. Antimicrobial peptides (AMPs) as drug candidates: A patent review (2003-2015). Expert Opin. Ther. Pat. 2016, 26, 689-702. [CrossRef] [PubMed]

131. Vincent, J.-L.; Marshall, J.C.; Dellinger, R.P.; Simonson, S.G.; Guntupalli, K.; Levy, M.M.; Singer, M.; Malik, R. Talactoferrin in Severe Sepsis: Results From the Phase II/III Oral tAlactoferrin in Severe sepsIS Trial. Crit. Care Med. 2015, 43, 1832-1838. [CrossRef]

132. Wach, A.; Dembowsky, K.; Dale, G.E. Pharmacokinetics and Safety of Intravenous Murepavadin Infusion in Healthy Adult Subjects Administered Single and Multiple Ascending Doses. Antimicrob. Agents Chemother. 2018, 62, e02355-17. [CrossRef]

133. Mahlapuu, M.; Håkansson, J.; Ringstad, L.; Björn, C. Antimicrobial Peptides: An Emerging Category of Therapeutic Agents. Front. Cell. Infect. Microbiol. 2016, 6, 194. [CrossRef] [PubMed]

134. Dijksteel, G.S.; Ulrich, M.M.W.; Middelkoop, E.; Boekema, B.K.H.L. Review: Lessons Learned From Clinical Trials Using Antimicrobial Peptides (AMPs). Front. Microbiol. 2021, 12, 287. [CrossRef] [PubMed]

135. Nilsson, A.C.; Janson, H.; Wold, H.; Fugelli, A.; Andersson, K.; Håkangård, C.; Olsson, P.; Olsen, W.M. LTX-109 Is a Novel Agent for Nasal Decolonization of Methicillin-Resistant and -Sensitive Staphylococcus aureus. Antimicrob. Agents Chemother. 2015, 59, 145-151. [CrossRef] [PubMed]

136. Sun, H.; Hong, Y.; Xi, Y.; Zou, Y.; Gao, J.; Du, J. Synthesis, Self-Assembly, and Biomedical Applications of Antimicrobial Peptide-Polymer Conjugates. Biomacromolecules 2018, 19, 1701-1720. [CrossRef] [PubMed]

137. Ugurlu, T.; Turkoglu, M.; Gurer, U.S.; Akarsu, B.G. Colonic delivery of compression coated nisin tablets using pectin/HPMC polymer mixture. Eur. J. Pharm. Biopharm. 2007, 67, 202-210. [CrossRef]

138. Yüksel, E.; Karakeçili, A. Antibacterial activity on electrospun poly(lactide-co-glycolide) based membranes via Magainin II grafting. Mater. Sci. Eng. C 2014, 45, 510-518. [CrossRef] [PubMed]

139. Chen, W.-Y.; Chang, H.-Y.; Lu, J.-K.; Huang, Y.-C.; Harroun, S.G.; Tseng, Y.-T.; Li, Y.-J.; Huang, C.-C.; Chang, H.-T. Self-Assembly of Antimicrobial Peptides on Gold Nanodots: Against Multidrug-Resistant Bacteria and Wound-Healing Application. Adv. Funct. Mater. 2015, 25, 7189-7199. [CrossRef]

140. Sharma, D.; Choudhary, M.; Vashistt, J.; Shrivastava, R.; Bisht, G.S. Cationic antimicrobial peptide and its poly-N-substituted glycine congener: Antibacterial and antibiofilm potential against A. baumannii. Biochem. Biophys. Res. Commun. 2019, 518, 472-478. [CrossRef]

141. Kim, H.; Jang, J.H.; Kim, S.C.; Cho, J.H. Development of a novel hybrid antimicrobial peptide for targeted killing of Pseudomonas aeruginosa. Eur. J. Med. Chem. 2020, 185, 111814. [CrossRef] [PubMed]

142. Mohid, S.A.; Ghorai, A.; Ilyas, H.; Mroue, K.H.; Narayanan, G.; Sarkar, A.; Ray, S.K.; Biswas, K.; Bera, A.K.; Malmsten, M.; et al. Application of tungsten disulfide quantum dot-conjugated antimicrobial peptides in bio-imaging and antimicrobial therapy. Colloids Surf. B Biointerfaces 2019, 176, 360-370. [CrossRef]

143. Lenhard, J.R.; Nation, R.L.; Tsuji, B.T. Synergistic combinations of polymyxins. Int. J. Antimicrob. Agents 2016, 48, 607-613. [CrossRef]

144. Otvos, L., Jr.; Ostorhazi, E.; Szabo, D.; Zumbrun, S.D.; Miller, L.L.; Halasohoris, S.A.; Desai, P.D.; Int Veldt, S.M.; Kraus, C.N. Synergy Between Proline-Rich Antimicrobial Peptides and Small Molecule Antibiotics against Selected Gram-Negative Pathogens in vitro and in vivo. Front. Chem. 2018, 6, 309. [CrossRef] [PubMed]

145. Brophy, J.A.; Voigt, C.A. Antisense transcription as a tool to tune gene expression. Mol. Syst. Biol. 2016, 12, 854. [CrossRef] [PubMed]

146. Pita, T.; Feliciano, J.R.; Leitão, J.H. Extracellular RNAs in bacterial infections: From emerging key players on host-pathogen interactions to exploitable biomarkers and therapeutic targets. Int. J. Mol. Sci. 2020, 21, 9634. [CrossRef]

147. Millar, J.A.; Raghavan, R. Modulation of Bacterial Fitness and Virulence Through Antisense RNAs. Front. Cell. Infect. Microbiol. 2021, 10, 596277. [CrossRef]

148. Sully, E.K.; Geller, B.L. Antisense antimicrobial therapeutics. Curr. Opin. Microbiol. 2016, 33, 47-55. [CrossRef] [PubMed]

149. Roberts, T.C.; Langer, R.; Wood, M.J.A. Advances in oligonucleotide drug delivery. Nat. Rev. Drug Discov. 2020, $19,673-694$. [CrossRef]

150. Jani, S.; Ramirez, M.S.; Tolmasky, M.E. Silencing Antibiotic Resistance with Antisense Oligonucleotides. Biomedicines 2021, 9 , 416. [CrossRef]

151. Hegarty, J.P.; Stewart, D.B. Advances in therapeutic bacterial antisense biotechnology. Appl. Microbiol. Biotechnol. 2018, 102, 1055-1065. [CrossRef]

152. Wesolowski, D.; Alonso, D.; Altman, S. Combined effect of a peptide-morpholino oligonucleotide conjugate and a cell-penetrating peptide as an antibiotic. Proc. Natl. Acad. Sci. USA 2013, 110, 8686-8689. [CrossRef]

153. Patenge, N.; Pappesch, R.; Krawack, F.; Walda, C.; Mraheil, M.A.; Jacob, A.; Hain, T.; Kreikemeyer, B. Inhibition of Growth and Gene Expression by PNA-peptide Conjugates in Streptococcus pyogenes. Mol. Ther. Nucleic Acids 2013, 2, e132. [CrossRef] [PubMed] 
154. Barkowsky, G.; Lemster, A.-L.; Pappesch, R.; Jacob, A.; Krüger, S.; Schröder, A.; Kreikemeyer, B.; Patenge, N. Influence of Different Cell-Penetrating Peptides on the Antimicrobial Efficiency of PNAs in Streptococcus pyogenes. Mol. Ther. Nucleic Acids 2019, 18, 444-454. [CrossRef] [PubMed]

155. Równicki, M.; Pieńko, T.; Czarnecki, J.; Kolanowska, M.; Bartosik, D.; Trylska, J. Artificial Activation of Escherichia coli mazEF and hipBA Toxin-Antitoxin Systems by Antisense Peptide Nucleic Acids as an Antibacterial Strategy. Front. Microbiol. 2018, 9, 2870. [CrossRef]

156. Liang, S.; He, Y.; Xia, Y.; Wang, H.; Wang, L.; Gao, R.; Zhang, M. Inhibiting the growth of methicillin-resistant Staphylococcus aureus in vitro with antisense peptide nucleic acid conjugates targeting the ftsZ gene. Int. J. Infect. Dis. 2015, 30, 1-6. [CrossRef]

157. Oh, E.; Zhang, Q.; Jeon, B. Target optimization for peptide nucleic acid (PNA)-mediated antisense inhibition of the CmeABC multidrug efflux pump in Campylobacter jejuni. J. Antimicrob. Chemother. 2014, 69, 375-380. [CrossRef] [PubMed]

158. Jeon, B.; Zhang, Q. Sensitization of Campylobacter jejuni to fluoroquinolone and macrolide antibiotics by antisense inhibition of the CmeABC multidrug efflux transporter. J. Antimicrob. Chemother. 2009, 63, 946-948. [CrossRef]

159. Wang, X.; Wang, Y.; Ling, Z.; Zhang, C.; Fu, M.; Wang, Y.; Wang, S.; Zhang, S.; Shen, Z. Peptide nucleic acid restores colistin susceptibility through modulation of MCR-1 expression in Escherichia coli. J. Antimicrob. Chemother. 2020, 75, 2059-2065. [CrossRef] [PubMed]

160. Wang, H.; Meng, J.; Jia, M.; Ma, X.; He, G.; Yu, J.; Wang, R.; Bai, H.; Hou, Z.; Luo, X. oprM as a new target for reversion of multidrug resistance in Pseudomonas aeruginosa by antisense phosphorothioate oligodeoxynucleotides. FEMS Immunol. Med. Microbiol. 2010, 60, 275-282. [CrossRef]

161. Al Husseini, L.B.; Maleki, A.; Al Marjani, M.F. Antisense mqsR-PNA as a putative target to the eradication of Pseudomonas aeruginosa persisters. New Microbes New Infect. 2021, 41, 100868. [CrossRef]

162. Pereira, S.; Santos, R.S.; Moreira, L.; Guimarães, N.M.; Braeckmans, K.; De Smedt, S.C.; Azevedo, N.F. Delivery of Oligonucleotides into Bacteria by Fusogenic Liposomes. Methods Mol. Biol. 2021, 2246, 87-96.

163. Kauss, T.; Arpin, C.; Bientz, L.; Vinh Nguyen, P.; Vialet, B.; Benizri, S.; Barthélémy, P. Lipid oligonucleotides as a new strategy for tackling the antibiotic resistance. Sci. Rep. 2020, 10, 1054. [CrossRef]

164. Eller, K.A.; Aunins, T.R.; Courtney, C.M.; Campos, J.K.; Otoupal, P.B.; Erickson, K.E.; Madinger, N.E.; Chatterjee, A. Facile accelerated specific therapeutic (FAST) platform develops antisense therapies to counter multidrug-resistant bacteria. Commun. Biol. 2021, 4, 331. [CrossRef] [PubMed]

165. Aunins, T.R.; Erickson, K.E.; Chatterjee, A. Transcriptome-based design of antisense inhibitors potentiates carbapenem efficacy in CRE Escherichia coli. Proc. Natl. Acad. Sci. USA 2020, 117, 30699-30709. [CrossRef]

166. Geller, B.L.; Deere, J.; Tilley, L.; Iversen, P.L. Antisense phosphorodiamidate morpholino oligomer inhibits viability of Escherichia coli in pure culture and in mouse peritonitis. J. Antimicrob. Chemother. 2005, 55, 983-988. [CrossRef]

167. Castillo, J.I.; Równicki, M.; Wojciechowska, M.; Trylska, J. Antimicrobial synergy between mRNA targeted peptide nucleic acid and antibiotics in E. coli. Bioorg. Med. Chem. Lett. 2018, 28, 3094-3098. [CrossRef] [PubMed]

168. Hansen, A.M.; Bonke, G.; Hogendorf, W.F.J.; Björkling, F.; Nielsen, J.; Kongstad, K.T.; Zabicka, D.; Tomczak, M.; Urbas, M.; Nielsen, P.E.; et al. Microwave-assisted solid-phase synthesis of antisense acpP peptide nucleic acid-peptide conjugates active against colistin- and tigecycline-resistant E. coli and K. pneumoniae. Eur. J. Med. Chem. 2019, 168, 134-145. [CrossRef]

169. Yavari, N.; Goltermann, L.; Nielsen, P.E. Uptake, Stability, and Activity of Antisense Anti-acpP PNA-Peptide Conjugates in Escherichia coli and the Role of SbmA. ACS Chem. Biol. 2021, 16, 471-479. [CrossRef]

170. Sully, E.K.; Geller, B.L.; Li, L.; Moody, C.M.; Bailey, S.M.; Moore, A.L.; Wong, M.; Nordmann, P.; Daly, S.M.; Sturge, C.R.; et al. Peptide-conjugated phosphorodiamidate morpholino oligomer (PPMO) restores carbapenem susceptibility to NDM-1-positive pathogens in vitro and in vivo. J. Antimicrob. Chemother. 2017, 72, 782-790. [PubMed]

171. Geller, B.L.; Marshall-Batty, K.; Schnell, F.J.; McKnight, M.M.; Iversen, P.L.; Greenberg, D.E. Gene-silencing antisense oligomers inhibit acinetobacter growth in vitro and in vivo. J. Infect. Dis. 2013, 208, 1553-1560. [CrossRef]

172. Lopez, C.; Arivett, B.A.; Actis, L.A.; Tolmasky, M.E. Inhibition of AAC(6')-Ib-Mediated Resistance to Amikacin in Acinetobacter baumannii by an Antisense Peptide-Conjugated 2', 4'-Bridged Nucleic Acid-NC-DNA Hybrid Oligomer. Antimicrob. Agents Chemother. 2015, 59, 5798-5803. [CrossRef]

173. Soler Bistué, A.J.C.; Martín, F.A.; Vozza, N.; Ha, H.; Joaquín, J.C.; Zorreguieta, A.; Tolmasky, M.E. Inhibition of aac $\left(6^{\prime}\right)$-Ib-mediated amikacin resistance by nuclease-resistant external guide sequences in bacteria. Proc. Natl. Acad. Sci. USA 2009, 106, 13230-13235. [CrossRef]

174. Martínez-Guitián, M.; Vázquez-Ucha, J.C.; Álvarez-Fraga, L.; Conde-Pérez, K.; Bou, G.; Poza, M.; Beceiro, A. Antisense inhibition of $l p x B$ gene expression in Acinetobacter baumannii by peptide-PNA conjugates and synergy with colistin. J. Antimicrob. Chemother. 2020, 75, 51-59. [CrossRef]

175. Sarno, R.; Ha, H.; Weinsetel, N.; Tolmasky, M.E. Inhibition of aminoglycoside 6 -N-acetyltransferase type Ib-mediated amikacin resistance by antisense oligodeoxynucleotides. Antimicrob. Agents Chemother. 2003, 47, 3296-3304. [CrossRef]

176. Arivett, B.A.; Fiester, S.E.; Ream, D.C.; Centrón, D.; Ramírez, M.S.; Tolmasky, M.E.; Actis, L.A. Draft Genome of the MultidrugResistant Acinetobacter baumannii Strain A155 Clinical Isolate. Genome Announc. 2015, 3, e00212-15. [CrossRef]

177. Ramirez, M.S.; Xie, G.; Marshall, S.H.; Hujer, K.M.; Chain, P.S.G.; Bonomo, R.A.; Tolmasky, M.E. Multidrug-resistant (MDR) Klebsiella pneumoniae clinical isolates: A zone of high heterogeneity (HHZ) as a tool for epidemiological studies. Clin. Microbiol. Infect. 2012, 18, E254-E258. [CrossRef] 
178. Howard, J.J.; Sturge, C.R.; Moustafa, D.A.; Daly, S.M.; Marshall-Batty, K.R.; Felder, C.F.; Zamora, D.; Yabe-Gill, M.; Labandeira-Rey, M.; Bailey, S.M.; et al. Inhibition of Pseudomonas aeruginosa by Peptide-Conjugated Phosphorodiamidate Morpholino Oligomers. Antimicrob. Agents Chemother. 2017, 61, e01938-16. [CrossRef]

179. Montagner, G.; Bezzerri, V.; Cabrini, G.; Fabbri, E.; Borgatti, M.; Lampronti, I.; Finotti, A.; Nielsen, P.E.; Gambari, R. An antisense peptide nucleic acid against Pseudomonas aeruginosa inhibiting bacterial-induced inflammatory responses in the cystic fibrosis IB3-1 cellular model system. Int. J. Biol. Macromol. 2017, 99, 492-498. [CrossRef] [PubMed]

180. Tekintas, Y.; Demir-Dora, D.; Erac, B.; Erac, Y.; Yilmaz, O.; Aydemir, S.S.; Kocagoz, Z.T.; Hosgor-Limoncu, M. Silencing acpP gene via antisense oligonucleotide-niosome complex in clinical Pseudomonas aeruginosa isolates. Res. Microbiol. 2021, $172,103834$. [CrossRef] [PubMed]

181. Greenberg, D.E.; Marshall-Batty, K.R.; Brinster, L.R.; Zarember, K.A.; Shaw, P.A.; Mellbye, B.L.; Iversen, P.L.; Holland, S.M.; Geller, B.L. Antisense phosphorodiamidate morpholino oligomers targeted to an essential gene inhibit Burkholderia cepacia complex. J. Infect. Dis. 2010, 201, 1822-1830. [CrossRef]

182. Sawyer, A.J.; Wesolowski, D.; Gandotra, N.; Stojadinovic, A.; Izadjoo, M.; Altman, S.; Kyriakides, T.R. A peptide-morpholino oligomer conjugate targeting Staphylococcus aureus gyrA mRNA improves healing in an infected mouse cutaneous wound model. Int. J. Pharm. 2013, 453, 651-655. [CrossRef] [PubMed]

183. Meng, J.; Da, F.; Ma, X.; Wang, N.; Wang, Y.; Zhang, H.; Li, M.; Zhou, Y.; Xue, X.; Hou, Z.; et al. Antisense growth inhibition of methicillin-resistant Staphylococcus aureus by locked nucleic acid conjugated with cell-penetrating peptide as a novel FtsZ inhibitor. Antimicrob. Agents Chemother. 2015, 59, 914-922. [CrossRef] [PubMed]

184. Goh, S.; Loeffler, A.; Lloyd, D.H.; Nair, S.P.; Good, L. Oxacillin sensitization of methicillin-resistant Staphylococcus aureus and methicillin-resistant Staphylococcus pseudintermedius by antisense peptide nucleic acids in vitro. BMC Microbiol. 2015, 15, 262. [CrossRef]

185. Meng, J.; He, G.; Wang, H.; Jia, M.; Ma, X.; Da, F.; Wang, N.; Hou, Z.; Xue, X.; Li, M.; et al. Reversion of antibiotic resistance by inhibiting mecA in clinical methicillin-resistant Staphylococci by antisense phosphorothioate oligonucleotide. J. Antibiot. 2015, 68, 158-164. [CrossRef]

186. Bai, H.; Sang, G.; You, Y.; Xue, X.; Zhou, Y.; Hou, Z.; Meng, J.; Luo, X. Targeting RNA polymerase primary $\sigma 70$ as a therapeutic strategy against methicillin-resistant Staphylococcus aureus by antisense peptide nucleic acid. PLoS ONE 2012, 7, e29886. [CrossRef]

187. Abushahba, M.F.N.; Mohammad, H.; Thangamani, S.; Hussein, A.A.A.; Seleem, M.N. Impact of different cell penetrating peptides on the efficacy of antisense therapeutics for targeting intracellular pathogens. Sci. Rep. 2016, 6, 20832. [CrossRef]

188. Rajasekaran, P.; Alexander, J.C.; Seleem, M.N.; Jain, N.; Sriranganathan, N.; Wattam, A.R.; Setubal, J.C.; Boyle, S.M. Peptide nucleic acids inhibit growth of Brucella suis in pure culture and in infected murine macrophages. Int. J. Antimicrob. Agents 2013, 41, 358-362. [CrossRef]

189. Matthews, H.; Hanison, J.; Nirmalan, N. ‘Omics'-informed drug and biomarker discovery: Opportunities, challenges and future perspectives. Proteomes 2016, 4, 28. [CrossRef] 